\title{
Cellular Defences of the Lung: Comparative Perspectives
}

\author{
J.N. Maina \\ Department of Zoology, \\ University of Johannesburg, \\ Johannesburg, \\ South Africa
}

'Our lungs are highly complex organs that are exquisitely specialized for gas exchange and host defense.'

Rawlins (2010)

\section{Introduction}

\subsection{General considerations}

The most important function of the lung is to acquire molecular oxygen and eliminate carbon dioxide. Except probably for the gastrointestinal system, no other organ in the body interacts with the external environment as constantly and as intimately as the respiratory system. For example, during a 24 hour period, at rest, the human lung is ventilated $\sim 25,000$ times with $\sim 20,000 \mathrm{~L}$ of air (e.g. Burri, 1985; Brain, 1996), it has a respiratory surface area (RSA) of $\sim 140 \mathrm{~m}^{2}$ (about the size of a tennis court) which is located in the acini that lie no more than 40 to $50 \mathrm{~cm}$ from the external environment (air) (e.g. Weibel, 1984), and the thickness of the blood-gas (tissue) barrier (BGB) (harmonic mean thickness, $\tau$ ht) is $0.62 \mu \mathrm{m}$, a value about one-fiftieth of the thickness of a foolscap paper or that of a human head hair (Gehr et al., 1978, 1990a). By weight, each day, more than $20 \mathrm{~kg}$ of air enters and leaves the human body, a load that far exceeds that of food and water ingested during the same time period (Brain, 1996). Depending on the level of air pollution, different types and quantities of foreign particulates and microbial pathogens are inhaled. While large RSA and thin BGB increase gas exchange, the concomitant downside to these structural properties is that they make the lung a leading portal of entry and therefore attack by pathogenic micro-organisms, damage by allergens and particulates, and injury by noxious gases (e.g. Brain, 1984, 1992; Lambrecht et al. 2001; Garn et al., 2006). The inhaled particulates are deposited on the epithelial lining of the conducting airways and that of the peripheral air spaces where they are retained for various durations before they are removed or destroyed (e.g. Geiser et al., 1988; Gehr et al., $1990 \mathrm{a}, \mathrm{b}$ ). Brain (1996) observed that 'the lung is unique in that the marriage between environment and lung disease is profound. The respiratory system threfore forms a huge challenge to the body's immune integrity (e.g. von Garnier and Nicod, 2009). 
According to the United Nations Environmental Program (UNEP) and the WHO Report of 1994 (UNEP-WHO, 1994), annual averages of $600 \mathrm{mg} / \mathrm{cm}^{3}$ and peak concentrations that may exceed $1,000 \mathrm{mg} / \mathrm{cm}^{3}$ of solid particles occur in the air that covers many of the world's large metropolis. The frequency and severity of respiratory diseases that arise from inhalation of airborne particles are on the increase (e.g. EPS, 1996; Peters et al., 1997; Wichman and Peters, 2000; Warheit et al., 2009). Epidemiological studies have shown that even moderate inhalation of particulates, especially those of a diameter $<10 \mu \mathrm{m}\left(\mathrm{PM}_{10}\right)$, cause high morbidity and mortality not only from respiratory but also from cardiovascular diseases, especially in individuals with pre-existing medical conditions (e.g. Dockery et al., 1993; Schwartz, 1994; Brunekreef et al., 1995; Ware, 2000; Pope, 2000; Nemmar et al., 2002; Pope et al., 2002; Suwa et al., 2002; Schulz et al., 2005; Kaufman, 2010; Brook et al., 2010; van den Hooven et al., 2011; Kampfrath et al., 2011). $\mathrm{PM}_{2.5}$ cause airway inflammation that presents in form of influx of committed monocytes, even in healthy individuals (Schaumann et al., 2004). Pulmonary afflictions and diseases have considerable socioeconomic impact. For example, in the United Kingdom, in 2006 more people died from respiratory diseases than from coronary disease or cancer and the cost to the National Health Service (NHS) was over £6.6 billion (BTS, 2006). According to the National Institutes of Health (NIH), in the United States, people suffer an average 1 billion colds per year and in 2006 the country spent more than 3 billion dollars to investigate respiratory-related diseases (http://www3.niaid.nih.gov/topics/commonCold/). Over $10 \%$ of hospitalizations and in excess of $16 \%$ of deaths in Canada are attributed to respiratory diseases (http://www.phac-aspc.gc.ca/ccdpc-cpcmc/crdmrc/facts_gen_e.html). According to the Canadian Lung Association (CLA), the economic burden of respiratory disease in the Country is $\sim 3$ billion (\$US) dollars (http://www.bukisa.com/articles/455926_lung-health-occupational-health-

incidence\#ixzz1I4jwMvBX). Based on net changes in gross domestic product (GDP) growth forecasts, the estimated annual cost of SARS (Sudden Avian Respiratory Syndrome) in Asia exceeds 10 billion dollars (\$US) (Lee and McKibbin, 2003; Fan, 2003; McKibbin and Sidorenko, 2006) and according to the World Bank's estimates, an influenza pandemic may result in a loss (expenditure) of 800 billion dollars (\$US) (Brahmbhatt, 2005): each year, seasonal influenza affects 5\%-15\% of the population in the northern hemisphere, with some some 3-5 million infections worldwide requiring hospitalization or leading to death (Sanders et al., 2011; http://www.euro.who.int/en/what-wedo/health-topics/diseases-and-conditions/influenza/seasonal-influenza 2010). For poultry, an important relatively more affordable source of animal protein, worldwide losses from respiratory diseases are estimated to cost the broiler industry over 1 billion dollars (\$US) annually (e.g. Dekich, 1997; Currie, 1999; Wideman, 2005). Because avian species form an important reservoir of human infections, it is vital to study and understand avian toll-like receptors and related recetors so as to both design vaccine adjuvants and substitutes to the widespread application of antibiotics and in selection of strains of birds with augmented pathogen resistance.

By exerting direct selective pressure and evolving novel strategies of evading and surviving host defences (e.g. Litman et al., 1993; DuPasquier, 1993; Bartl et al., 1994; Beck and Habicht, 1996; Spurgin and Richardson, 2010; Finlay and Buckner, 2011), microbial pathogens have directly and indirectly fundamentally shaped the genetic and the phenotypic diversity of life. One of the most complex and astounding biological designs - the immune system - by 
which 'non-self' is recognized, neutralized, and eliminated has developed to counter continuous assaults (e.g. Janeway, 1993; Beck et al. 1994; Litman, 1996; Beck and Habicht, 1996; Wang et al., 2011; Yewdell and Dolan, 2011; McClung, 2011). In vertebrates, the genes for the major histocompatibility complex show how natural selection maintains variation in wild-populations of animals (e.g. Klein, 1986; Hughes and Neil, 1989; Apanius et al., 1997; Hughes, 1999; Meyer and Thompson, 2001; Hess and Edwards, 2002; Meyer and Mack, 2003). A diverse and extensive immune defence system that comprises of cellular (innate $=$ natural)- and immunological (adaptive $=$ acquired $=$ specific) immunities have formed for protection (Fig. 1). The innate immune system which predominates in plants, fungi, insects, and the primitive multicellular organisms is believed to have formed first (e.g. Litman et al., 1993; DuPasquier, 1993; Bartl et al., 1994; Beck and Habicht, 1996; Hazlett and Wu, 2011). Invertebrates lack lymphocytes and antibody (immunoglobulin) based humoral immune system while lectins which are found in plants, bacteria, invertebrates, and vertebrates should have developed earlier (e.g. DuPasquier 1993; Beck et al., 1994). In certain interesting ways, the immunities of the sharks and skates are similar to the human one (e.g. Litman 1996). Many aspects of the invertebrate host defense mechanisms and their control signals have been conserved and carried over from lower to higher orders of animals (e.g. Mulnix and Dunn, 1995; Brownlie and Allan, 2011).

While among vertebrates host defences have been well-studied, mainly in the laboratory mammals and in the humans (e.g. Green et al., 1977; Johnson and Philip, 1977; Geiser, 2002; Whitset, 2002; Alexis et al., 2006), birds have only been modestly investigated (e.g. Ochs et al., 1988; Maina and Cowley, 1998; Nganpiep and Maina, 2002; Reese et al., 2006), and only scanty details exist on amphibians and reptiles (e.g. Bargmann, 1936; Grant et al., 1981; Welsch, 1981, 1983; Maina, 1989; Conlon, 2011). The need to understand immunological- and cellular defences in different animal taxa is becoming more important because of the most recent flare-up of high morbidity and mortality zoonotic infectious diseases, e.g., bovine spongiform encephalopathy, hemorrhagic fever, swine influenza, avian influenza H5N1, hantavirus, West Nile virus disease, Nipah virus, Rabies, leptospirosis, Rift Valley fever, and lyme disease (e.g. Rehman, 1998; Field et al., 2001; Cleaveland et al., 2001; Burroughs et al., 2002; Krauss et al., 2003; Chen et al., 2004; Brown, 2004; Chomel et al., 2007; Greger, 2007). The term 'zoonosis' was coined by Rudolph Virchow (1821-1902) in his studies of the pig muscle parasite, Trichnella. Factors like increase of human population and consequently ecological pressures on land leading to relocation to totally new habitats (e.g. Tilman et al., 2001; Daszak et al., 2001; Patz and Wolfe, 2002; Patz et al., 2004) and globalization with its rapid mass movement of people, animals, animal products, and global warming (e.g. IPCC, 2007; Sachan and Singh, 2010; Mills et al., 2010) are some of the factors that have been implicated in the recent outbreaks of zoonotic diseases (e.g. Burroughs et al., 2002). Comparative immunology has shown some esoteric immune related systems and substances that have potential for use as medications for humans (Boman and Hultmark, 1987; Hoffman and Hetru, 1992; Litman, 1996; Beck and Habicht, 1996).

The term 'macrophage', which derives from Greek, means 'large eaters'; a phagocyte literally means 'eating cell'; and, to 'phagocytose' means 'to eat'. Large leukocytic cells which in tissues differentiate into organ- specific (dedicated) subpopulations, macrophages move between tissue compartments in pursuit of invading pathogens and harmful particulates. The phagocytic cells of the immune system include macrophages, neutrophils, 
and dendritic cells. On activation by an antigen, phagocytes release and/or react to a group of highly specialized molecular signals called cytokines, e.g., interferons, interleukins (e.g. IL-1 and IL-6), and tumour necrosis factor (TNF) (e.g. Beck and Habicht, 1991; Gerlach et al., 2011). They also recognize and usually eliminate 'altered self', i.e., cells or tissues that have died, commonly by programmed cell death (apoptosis) or have changed by injury or disease like cancer.

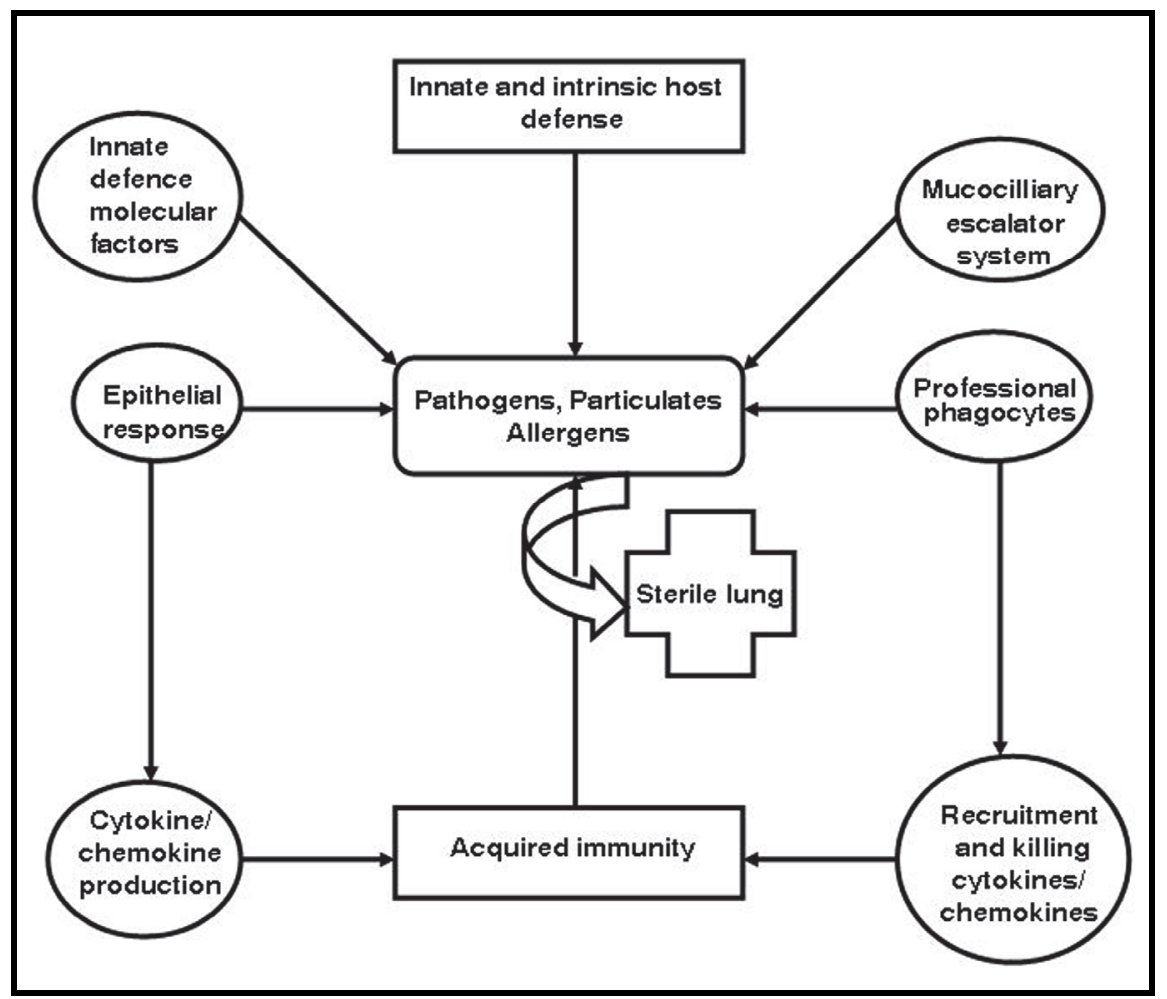

Fig. 1. The sterility of the lung is maintained by complex and efficient interplay of innate(cellular) and acquired immune factors/systems. Pathogens and particulates that gain enty into it are neutralized, removed or sequestered.

Macrophages form an important part of the innate immune system that comprises of a group of cells that instantly defend the host from infection in a non-specific (generic) manner. In contrast to acquired immunity, macrophages don't confer long-lasting or protective immunity to the host. The common strategies by which bacteria become pathogens were comprehensively reviewed by Finlay and Falkow (1997). It is evident that pathogenic bacteria evolved from related non-pathogenic microorganisms by genetically gaining relatively large parts of genetic material that encode for virulence factors rather than by slow, adaptive evolution of pre-existing genes (e.g. Blum et al., 1994, 1995; Lee, 1996; Cheetham and Katz, 1995; Finlay and Falkow, 1997) and that the relentless nature of the challenge (selective pressure) posed by pathogens on animals (and even on plants) affected 
the evolution of host genes, conceivablyby selecting for changes (genetic) that promote survival (Finlay and Falkow, 1997). This may have lead to sudden radical changes in the way antibody genes are organized (Litman, 1996). Pathogenic microorganisms appear to evolve in quantum leaps, normally by their gaining genetic segments (factors acquired from unrelated organisms) that encode for multiple virulences (Finlay and Falkow, 1997).

\begin{tabular}{|lc|}
\hline \multicolumn{1}{|c|}{ Definition of abbreviations } \\
AM & Alveolar macrophage \\
BEC & Bronchial epithelial cell \\
BGB & Blood-gas (tissue) barrier \\
BM & Bronchial macrophage \\
BMM & Bone marrow monocyte \\
DC & Dendritic cell \\
PIM & Pulmonary interstitial macrophage \\
PM & Pulmonary macrophage \\
PIVM & Pulmonary intravascular macrophage \\
PIM & Pleural macrophage \\
PSM & Pulmonary surface macrophage \\
ROS & Reactive oxygen species \\
\hline
\end{tabular}

\subsection{Pulmonary defences and macrophages}

Having a lot to do with the fact that it is continuously exposed to insults from inhaled particulates, allergens, noxious gases, and pathogens over a large surface area and across thin BGB (e.g. Gehr et al., 1978; Meban, 1980; Maina and King, 1982; Rohmann et al., 2011), directly and indirectly, the respiratory system is exceptionally well-defended (e.g. Brain, 1980, 1992; Bedoret et al., 2009) (Figs. 1, 2). Directly, it is endowed with a formidable number of mechanical, physical, and cellular defences which are augmented by inflammatory and immune responses (e.g. Nicod, 2005). The inventory includes: a) a cough reflex that mechanically removes deposited irritants (Eckert et al., 2006; Canning, 2008; Poth and Matfin, 2010); b) a surface lining (surfactant) (Schürch et al., 1990; Gehr et al., 1990a, b; Geiser et al., 2003; Gehr et al., 2006), c) the BGB (e.g. Gil and Weibel, 1971; Maina and King, 1982; Gehr et al., 1990a, b; Maina and West, 2005); d) ciliated, mucus covered epithelium that traps, destroys, and clears deposited particulates through a mucociliary escalator system (e.g. Kilburn, 1968; Lippmann and Schlesinger, 1984; Geiser et al., 1990, 2003; Whitsett, 2002; Callaghan and Voynow, 2006) (Figs. 3-6); e) motile phagocytic cells (macrophages) that engulf, destroy, and sequester harmful particulates and pathogens (e.g. Geiser et al., 1990; Nicod, 2005) (Figs. 7-14); f) epithelium endowed with tightly packed cells that physically stop and destroy harmful agents (e.g. Breeze and Wheeldon, 1977; Harkema et al., 1991; Godfrey, 1997; Maina and Cowley, 1998; Nicod, 2005; Nganpiep and Maina, 2002) (Fig. 4), and; g) strategically placed mucosal and bronchial lymphatic tissue that is involved in the dissolution and antibody labelling of foreign particulates (Fagerland and Arp, 1990, 1993; Crapo et al., 2000; Reese et al., 2006).

Considering the intensity and the regularity of daily attacks to which it is exposed, its capacity of adapting to shifting environmental conditions, and the relative infrequency of diseases, the efficiency of the defences of the respiratory system is bewildering. In actual 
fact, the mechanisms and processes are so proficient that when pulmonary diseases and/or other pathologies are absent, the respiratory system is practically sterile below the larynx (e.g. Laurenzi et al., 1964; Green and Kass, 1964; Brain, 1980, 1984; Fawcett, 1986; Warheit et al., 1988; Brain, 1988; Steinmüller et al., 2000; Whitsett, 2002). This level of 'cleanliness' emanates from the diverse, well-coordinated pulmonary host defences that adeptly neutralize pathogenic microorganisms like bacteria, fungi, viruses, and harmful particulates that are inhaled or brought to the lung through blood (e.g. Zetterberg et al., 1998; Laskin et al., 2001; Whitsett, 2002; Pabst and Tschernig, 2002; Camner et al., 2002; Tschernig et al., 2006; Moniuszko et al., 2007; Tschernig and Pabst, 2009).

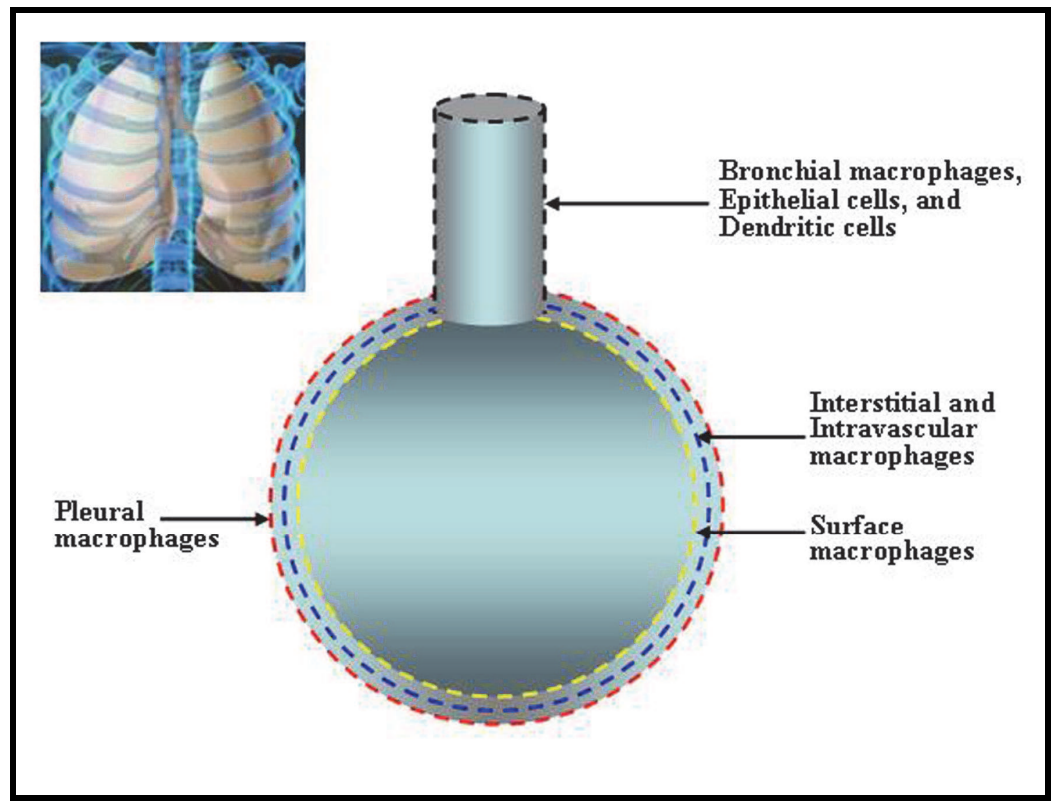

Fig. 2. Cellular defences of the respiratory system. Consistent with its high exposure to particulate matter and pathogenic microorganisms, the lung is very well-protected by various populations of phagocytic cells. Depending on need and circumstances, the cells can transfer from one compartment to another.

Among the cellular defences of the respiratory system, at the gas exchange level, pulmonary surface macrophages (PSMs) form the frontline defence of the lung. Highly specialized cells, macrophages clear dead host cells while defending against infection by broad range of pathogen-recognition receptor and their ability to produce inflammatory cytokines and chemokines that control the replication of the invaders (e.g. Gordon, 2002; Hazlett and Wu, 2011). Macrophages are highly specialized, robust motile cells that belong to a range of subpopulations: in different forms and locations, they display different behaviours and functions (e.g. Bowden, 1976; Dougherty and McBride, 1984; Lehnert, 1992; Brain, 1992; Gordon, 2002; Gordon and Taylor, 2005; Geissmann et al., 2010a, b; Schneberger et al., 2011). By detecting injurious agents, phagocytosing them, and acting as effector cells for both humoral and cell-mediated immune responses, macrophages serve as the frontline innate 
defence cells of the lung and as sentinels of the immune system of the body (e.g. Fels and Cohn, 1986; Peão et al., 1993; Warheit and Hartsky, 1993; Yamaya et al., 1995; Rubovitch et al., 2007). A relationship exists between the numbers of PSMs [like the alveolar macrophages (AMs)] with the level of environmental pollution (Brain, 1971, 1987; Nagdeve, 2004; Sichletidis et al., 2005; Mateen and Brook, 2011; Conklin, 2011). Even with an elegant defence inventory, respiratory diseases, especially those caused by air pollution, are on the increase (e.g. Peters et al., 1997; Mateen and Brook, 2011; Conklin, 2011). After the particles or pathogens have eluded or overwhelmed the epithelial barrier of the upper airways, they come into contact with the dedicated antigen presenting dendritic cells (DCs) (e.g. Steinman and Cohn, 1973; Nicod, 1997; Lipscomb and Masten, 2002; Holt, 2005) which are highly phagocytic (Dreher et al., 2001; Kiama et al., 2001, 2006; Walter et al., 2001). If they reach the alveolar surface, they are dealt with by the PSMs (e.g. Bowden, 1976; Goldstein and Bartlema, 1977; Geiser, 2002).

While macrophages are central to the defence of the lung from assaults by injurious materials and pathogenic agents (e.g. Holt et al., 1982; Brain, 1984; Weissler et al., 1986), their roles extend beyond engulfing (phagocytosing) and neutralizing harmful agents. They are secretory and regulatory and control activities of other cells like neutrophils, lymphocytes, and fibroblasts (e.g. Adamson and Bowden, 1981). Contrary to their well-serving protective activities, under certain conditions, macrophages function as a 'double-edged sword': they can initiate, exacerbate, and prolong inflammatory responses that cause immune suppression and progression of pathologies like cancer, leading to higher morbidity and mortality (e.g. Brain, 1976, 1980, 1984, 1986, 1992; Brain et al., 1984; Bowden, 1987; Warner, 1996; Yanagawa et al., 1996; Fireman et al., 1999; Ishii et al., 2005; Parbhakar et al., 2005; Rubovitch et al., 2007; Shimotakahara et al., 2007; Sica and Bronte, 2007; Kaczmarek et al., 2008; Gill et al., 2008; Biswas et al., 2008; Aharonson-Raz and Singh, 2010; De Palma and Lewis, 2011).

In spite of their widely accepted common origin from the bone marrow, their hematogenetic origin (e.g. Brain, 1976, 1984; van Furth, 1982; Geiser, 2010), macrophages display great phenotypic and functional heterogeneity (Krombach et al., 1977; Nguyen et al., 1982; Lehnert, 1992; Warheit and Hartsky, 1993; Kiama et al., 2008). Local environments largely determine the structural and functional differences (e.g. Morrissette et al., 1999). Within and between animal species, the immune reactions, phagocytic competences, and the cytoenzymological properties of different groups of macrophages have been shown to be spatially compartmentalized: observations made on one population of macrophages may therefore not correctly apply to another. For example, the AMs have slower rate of phagocytosis, higher motility, and faster particle clearance compared to the pulmonary intervascular macrophages (PIVMs) (Molina and Brain, 2007). Compared to the human ones, the dog's AMs have relatively less cytoplamic motility when acutely exposed to cigarette smoke (Yamaya et al., 1989) and during acute asthmatic attack (Yamaya et al., 1990). Among rodents, the AMs of the rat lung are the most efficient in clearing inhaled iron particles while the hamster ones are recruited to the site of particle deposition by noncomplement-mediated mechanism (Warheit and Hartsky, 1993) while the hamster and guinea pig's AMs best respond to bacteria (Warheit et al., 1988). Compared to those of the rat, the PSMs of the bird lung phagocytose polystylene particles more efficiently (Kiama et al., 2008). 
The term 'pulmonary macrophage' (PM) loosely refers to cells that occupy two anatomical compartments of the lung: in the upper airways are the bronchial macrophages (BMs) and in the lower respiratory tract are the surface (free) macrophages (SMs) (e.g. Crowell et al., 1992). Other groups of phagocytes, however, exist in other parts of the lung. These are the dendritic cells (DCs), the pleural macrophages (PIMs), the pulmonary interstitial macrophages (PIMs), and in the lungs of certain species of animals the pulmonary intravascular macrophages (PIVMs). The structural attributes and the functional roles of these groups of cells are succinctly described below. To the best of my knowledge, this is the first comprehensive review of the biology of the PMs from a comparative perspective.

\section{Pulmonary surface (free) macrophages (PSMs)}

Acting as scavengers on the respiratory surface, the highly motile PSMs phagocytose, neutralize, and sequester harmful foreign materials (e.g. Sibille and Reynolds, 1990; Kelley, 1990; Lohmann-Matthes et al., 1994; Steinmüller et al., 2000). Also, by having receptor sites for immunoglobulins and complement on their cell membranes, PSMs contribute to the health of the lung by passing on specific information to immunologically competent cells like neutrophils, lymphocytes, and plasma cells, in so doing promoting antigen-antibody response (e.g. Said and Foda, 1989; Ooi et al., 1994). PSMs appear to stimulate and promote repair of epithelial cells after injury by releasing a growth factor (e.g. Takizawa et al., 1990). Interaction between PSMs and bronchial epithelial cells (BECs) during exposure to particulates with a diameter of less than $10 \mu \mathrm{m}\left(\mathrm{PM}_{10}\right)$ contributes to production of mediators (molecular factors) that induce a systematic inflammatory response (e.g. Hirano, 1996; Fujii et al., 2002; Ishii et al., 2005; Rubovitch et al., 2007).

Large, mononuclear cells, PSMs consist of several subtypes that can be categorized by criteria like size, morphology, numbers, motility, ingestion and handling of foreign materials, adherence onto surfaces, and expression of surface receptors (e.g. Brain, 1976, 1980, 1992; Zwilling et al., 1982; Nguyen et al., 1982; Holt et al., 1982; Warheit et al., 1984, 1986; Sebring and Lehnert, 1992; Spiteri et al., 1992; Lavnikova et al., 1993; Johansson et al., 1997). The existence of subpopulations of macrophages that have functionally distinct roles in airway immunity derives from the individual bone marrow precursor cells and the environment that they reside in (Gant and Hamblin 1985). Compared to the PIVMs, the rat PSMs exhibit marked microbial activity through high production of reactive oxygen species (ROS), nitric oxide (NO), and tumour necrotic factor-a (TNF-a) (Steinmüller et al., 2000). Exposure of rats to NO induces infiltration of AMs that are phenotypically and functionally different (regarding mediator mRNA expression and production as well as mRNA expression for several matrix metalloproteinases) from the resident AMs (Garn et al., 2006). Ensuing from infection or overwhelming by irritants, need for more macrophages is met by in situ replication of existing cells, release of pre-existing cells from various compartments (reservoirs) within the lung, increased production from macrophage precursors in the lung interstitium, and increased flux of monocytes from blood to the lung (e.g. Brain, 1980, 1992). The PSMs are renewed at a rate of $\sim 1-2 \%$ of the total number of cells in the lung (e.g. Shellito et al., 1987) daily.

The temporal sequence of particle clearance by phagocytes entails particle identification, endocytosis, and transport from the alveolar surface (Green, 1973, 1984; Warheit et al., 1984). Resting freely on the respiratory surface, PSMs are directly exposed to particulates, 


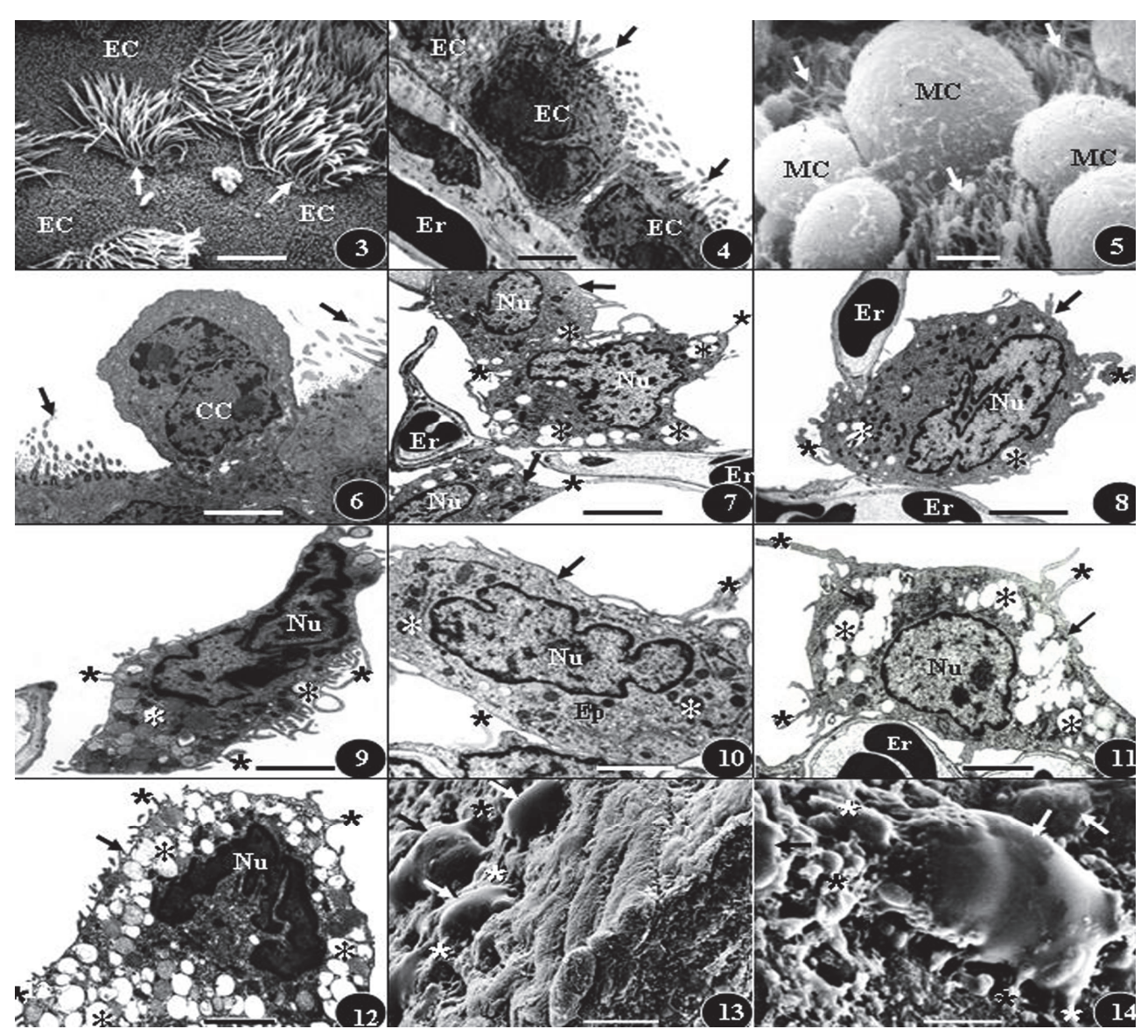

Fig. 3.-4. Bronchial epithelial cells (EC) that comprise of ciliated cells (arrows) and mucus secreting cells (MC). Er, erythrocyte. Fig. 5.-6. Respiratory epithelium at the bronchiole level showing Clara cells (CC) interspersed between ciliated cells (arrows). Figs. 7.-14. Surface macrophages (arrows) of the mammalian- (Figs. 7-12) and the frog lungs (Fig. 13. -14.). Stars, filopodia (feet); Er, erythrocyte; asterisks, lysosomes; $\mathrm{Nu}$, nucleus; Ep, epithelial cell. Scale bars: Figs. 3, $30 \mu \mathrm{m} ; 4,45 \mu \mathrm{m} ; 5,30 \mu \mathrm{m} ; 6,50 \mu \mathrm{m} ; 7,10 \mu \mathrm{m} ; 8,25 \mu \mathrm{m} ; 9,10 \mu \mathrm{m} ; 10,10 \mu \mathrm{m} ; 11$, $10 \mu \mathrm{m} ; 12,15, \mu \mathrm{m} ; 13,20 \mu \mathrm{m} ; 14,10 \mu \mathrm{m}$.

environmental toxicants, and pathogens. In contrast to fixed or interstitial macrophages that are attached to the collagenous fibers of the tissue matrix, they (PSMs) actively move over the respiratory surface by ameboid movement that entails formation of deformations of the cell membrane, leading to cytoplasmic extensions $($ advancing lamella $=$ filopodia $=$ pseudopodia) in the direction of the movement, pulling the main part of the cell with it (Figs. 10, 11, 13, 14). Actin-binding protein and myosin advance in the tips of the filopodia (Reaven and Axline, 1973; Stossel and Hartwig, 1976; Hartwig et al., 1977). In addition to effecting movement, formation of filopodial extensions by contractile proteins is involved in 
phagocytosis of foreign agents (Stossel, 1978; Zigmond and Hirsch, 1979). Cytoplasmic motility corresponds with phagocytic activity of PSMs: both cytoplasmic movement and phagocytosis may be regulated by similar mechanism in the cytoskeletal system (Yamaya et al., 1995). Once the phagocytosed particle is engulfed, i.e., is enclosed within the invaginated cell membrane and transferred to a cytoplasmic location, it is called a phagosome.

Macrophages are chemotactically driven to foreign materials/agents. The terms 'free', 'wandering', and 'fixed' macrophages refer to different functional states and/or stages of the development of cells of same cell phagocytic lineage. When stimulated, fixed macrophages detach from collagenous fibers and migrate as free macrophages to sites of pathogen invasion, injury, or irritation. PSMs remain motile up to a certain particle loading and beyond that the mobility is greatly inhibited (e.g. Yu et al., 1989; Lehnert et al., 1990; Kiama et al., 2008). For the avian PSMs (Kiama et al., 2008), the cells burst after ingesting high loads of polystylene particles (Figs. 15-17). Inability of dust-laden AMs to reach the mucociliary escalator system of the upper airways correlates with the particle loading (Morrow, 1988). In the Fischer 344 rat, when the loading exceeds $\sim 600 \mu^{3}$ per cell, particle clearance ceases and the particle laden cells remain in the alveolar region. Interestingly, PSMs can be overwhelmed by even small amounts of ingested particulates, e.g., carbon particles (concentration $0.2 \mu \mathrm{m} .10^{-6}$ ) and also by long term (22-44 hr) incubation with low concentrations (12.5 M.ml-1) of interferon- $\gamma$ (IFN- $\gamma$ ) (Lundborg et al., 1999, 2001). PSMs may also be rendered non-functional by exposure to inordinately high concentration of particulates or pathogens, especially where there are underlying infections that invoke increase in production of IFN-ץ (Baron et al., 1991; Cuffs et al., 1997; Camner et al., 2002).
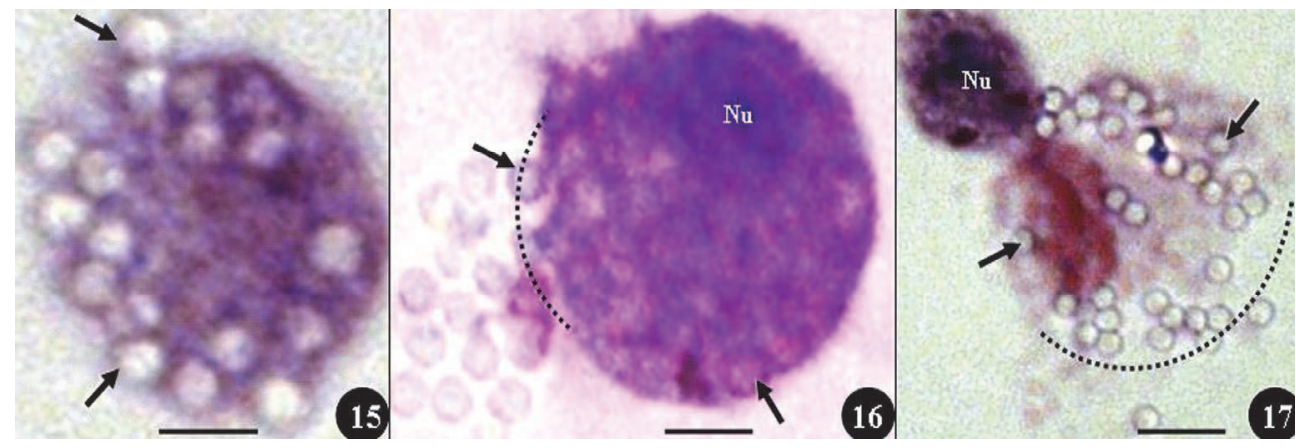

Fig. 15.-17. Pulmonary surface macrophages of the avian lung showing various stages of uptake of polystylene particles (arrows). At a certain critical point of particulate ingestion, the cells burst (dashed line). $\mathrm{Nu}$, nucleus. Scale bars: $3 \mu \mathrm{m}$.

The ultrastructural morphology of the AMs has been well-documented (e.g. Weibel, 1984, 1985). Remarkably heteromorphic, they vary in size from 10 to $40 \mu \mathrm{m}$ in diameter, constitute 2 to $9 \%$ of the pneumocytes, and have an indented (bean = horse shoe-shaped) eccentrically located nucleus (e.g. Sebring and Lehnert, 1992; Weibel, 1984, 1985) (Fig. 12). The nuclear indentation contains numerous vacuoles, Golgi apparati, rough endoplasmic reticulum, and mitochondria. The most striking structural features of the PSMs are the large number of membrane bound cytoplasmic inclusions that include lysosomes, phagososmes, vacuoles, and lipid droplets (Figs. 7, 11, 12). Many of the vacuoles are about $0.5 \mu \mathrm{m}$ or less in diameter 
and are oblong or spherical in shape. They contain high concentrations of various strong hydrolytic enzymes which are synthesized in the rough endoplasmic reticulum and packaged in the Golgi complex, forming the primary lysosomes. When the primary lysosomes combine with the phagosomes, they form the secondary lysosomes. The brokendown/detoxified foreign agents are either discharged from the cell or are stored in membrane bound granules called residual bodies. The foreign indigestible materials, e.g., carbon- and heavy metal particles, are sometimes permanently stored in the phagocytic cells of the lung. When macrophages are overwhelmed by large foreign materials that cannot be efficiently phagocytosed by individual cells, they form multinucleated giant cells that sequester such factors. Nodular inflammatory lesions that contain these cells are termed granulomas (e.g. Fawcett, 1986).

Although different views have been expressed by, e.g., Sorokin et al. (1984), it is now widely accepted that PSMs do not form in situ, i.e., in the lung: they belong to the general mononuclear phagocyte (formerly reticuloendothelial) system of the body and originate from stem cells in the bone marrow from where they are transported in blood as monocytes. On entering the interstitium of the lung they undergo a series of maturational stages before transferring to the surface (e.g. van Furth, 1970; Bowden and Adamson, 1980; Blussé van Oud Alblas et al., 1983; Bowden, 1987; Sebring and Lehnert, 1992; Brain et al., 1999; Geiser, 2010). The turnover time of the PSMs is $\sim 6$ days and amounts to $15.10^{3}$ cells per hour (Blussé van Oud Alblas et al., 1983). The fate of PSMs is varied: a) many of the cells leave the peripheral air spaces via the bronchi where they are transported by the mucociliary escalator system to the oral pharynx (e.g. Spritzer et al., 1968) to be swallowed or expectorated; b) others move to the interstitium and either settle there or leave via the lymphatics (e.g. Sorokin and Brain, 1975). Compared to the PIMs, AMs have greater phagocytic activity and faster attachment and ingestion properties (Franke-Ullmann et al., 1996; Fathi et al., 2001).

While pulmonary cellular defence appears to exist in the amphibian- (e.g. Welsch, 1981, 1983; Maina and Maloiy, 1988; Maina, 1989) (Figs. 13, 14) and reptilian lungs (Grant et al., 1981), PSMs are rare in the lungs of the lower vertebrates (Bargmann, 1936). Welsch (1983) experimentally stimulated a macrophagic response in the lung of Xenopus laevis after exposure and aspiration of carbon particles. In the caecilian lung, macrophages contain acid phosphatase, $\beta$-glucosaminidae, and unspecific esterase (Welsch, 1981). In the lungs of the lower vertebrates (Welsch and Müller 1980), epithelial cells (pneumocytes) contain acid phosphatase and have a phagocytic capacity. No resident surface macrophages occur in a nonchallenged lung of the snake, Boa constrictor (Grant et al., 1981): unphagocytosed materials remained on the respiratoty surface for up to 4 days. Challenge of the snake lung with inspirable particles increases surfactant secretion, elicits surfacing of nonphagocytic eosinophilic granulocytes, but interestingly doesn't set off release of mononuclear phagocytic macrophages (Grant et al., 1981).

While the biology of the AMs has been well-studied (e.g. Bowden, 1987), relatively little is known about the SMs of the avian respiratory system. Paucity of SMs (e.g. Stearns et al., 1986; Toth et al., 1988; Klika et al., 1996; Maina and Cowley, 1998; Nganpiep and Maina, 2002; Kiama et al., 2008) and even lack of them was reported by, e.g., Lorz and López (1997). In mice, rats, and guinea pigs, respectively, yields of $0.55-1.55 .10^{6}, 2.86-4.43 .10^{6}$, and 1.081.77.107 AMs were determined by Holt (1979). Some of these values are 20 times greater than 
those determined in much larger birds (e.g. Toth and Siegel, 1986). The average number of SMs in the lung of the pigeon, Columba livia is 1.6.105 (Maina and Cowley, 1998), in the domestic fowl, Gallus gallus variant domesticus it is 2.5.105 (Toth and Siegel, 1986; Toth et al., 1987), and in the turkey, Meleagris gallopavo is $1.15 .10^{6}$ (Ficken et al., 1986). The number of SMs per unit body mass in the rat was significantly greater than that of the domestic fowl and the duck, Cairina moschata (Nganpiep and Maina 2002) (Fig. 18). In a 30 year-old smoker and a nonsmoker, respectively, $1.5 .10^{7}$ and 5.2.10 $\mathrm{AMs}$ were harvested by bronchopulmonary lavage by Hof et al. (1990). Regarding cellular defence strategies, mechanisms, and proficiencies, it has been contended by different investigators, e.g., Klika et al. (1996) and Spira (1996) that compared to mammals, birds are relatively more susceptible to pulmonary diseases and afflictions. In the poultry industry, huge economical losses have been ascribed to mortalities arising from respiratory diseases (e.g. Mensah and Brain, 1982; Toth et al., 1988). Scarcity of SMs in the avian lung (e.g. Stearns et al., 1986; Maina and Cowley, 1998; Nganpiep and Maina, 2002; Kiama et al., 2008) and enzymatic deficiencies in the oxidative metabolism of the SMs (e.g. Penniall and Spitznagel, 1975; Bellavite et al., 1977) have been reported.

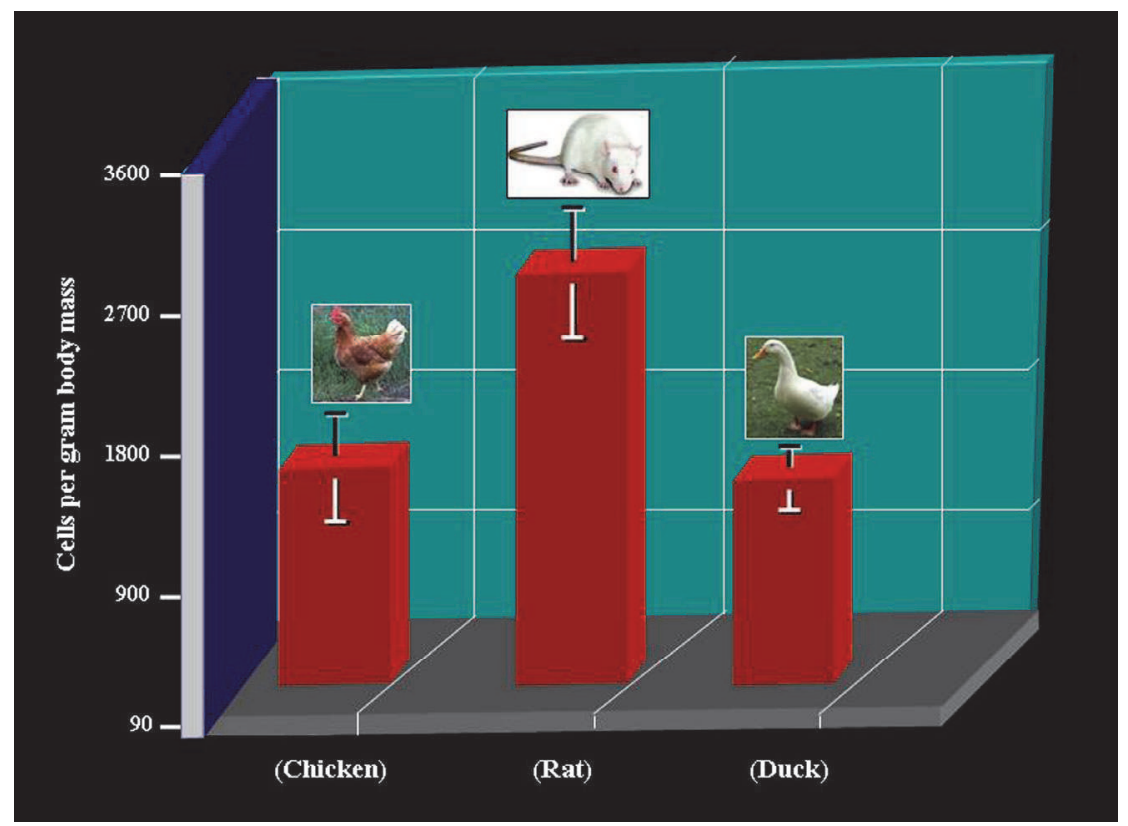

Fig. 18. Comparison between the numbers of pulmonary surface macrophages (PSMs) in the chicken (domestic fowl) (Gallus domesticus), the rat (Rattus rattus), and the duck (Cairina moschata). Birds have relatively fewer PMS compared to mammals. From Nganpiep and Maina (2002).

The foremost morphological and physiological factors that may predispose the avian respiratory system to injury by inspired foreign agents are: a) a relatively thin BGB and extensive RSA (e.g. Maina et al., 1989), b) large tidal volume and continuous and unidirectional ventilation of the lung (e.g. Fedde 1980, 1997; Brown et al., 1997), and c) in 
some species, e.g., the ostrich, Struthio camelus (Bezuidenhout et al., 2000), the air sacs extend out of the coelomic cavity to lie subcutaneously, where they are highly susceptible to trauma and infection: in such cases, air sacculitis (infection of the air sacs) can easily spread to the lung.Categorical proof that the avian lung is relatively more susceptible to infection by inhaled biological pathogens is lacking. It was argued by Maina (2005) that in the bird lung, PSMs, cells that are abundantly endowed with lysosomes (Nganpiep and Maina 2002) (Fig. 19-24) and have greater motility and phagocytic capacity (Kiama et al., 2008) may be so efficient that only few of them are required to reside on the respiratory surface and provide adequate protection. Pulmonary cellular defence is reinforced by capacity of rapidly mobilizing and transferring PIMs, PIVMs and probably blood monocytes to the respiratory surface (Nganpiep and Maina, 2002). Under similar conditions, birds may not be any more susceptible to pulmonary diseases than mammals. Factors like extreme genetic manipulation for faster growth and weight gain and the intensive and stressful regimes of battery production and management may explain the high incidence of aerosol transmitted pulmonary diseases, particularly in poultry.

\section{Pulmonary interstitial (subepithelial) macrophages (PIMs)}

Mainly because they are relatively less accessible, compared to the PSMs which are easily harvested by pulmonary lavage (e.g. Holt et al., 1985; Steinmüller et al., 2000), the PIMs have been relatively less well-studied. They are found in the peribronchial and perivascular spaces, in the interstitial spaces of the lung parenchyma (Fig. 25), in the lymphatic channels, and in the visceral pleural region (e.g. Bedoret et al., 2009; Nganpiep and Maina, 2002). Occurring in substantial numbers, PIMs provide bactericidal and immune mediated protection against particles and pathogens that escape the PSMs and penetrate the epithelium: there, they are sequestered or removed via the lymphatic channels. In the rat lung, PIMs form a substantial fraction of the PMs (e.g. Sebring and Lehnert, 1992): they comprise from $37 \%$ to $40 \%$ of the PMs (Lehnert et al., 1985; Crowell et al., 1992). However, using a different method, Blussé van Oud Alblas and van Furth (1979) determined that PIMs form only $7 \%$ of the PMs in the mouse-, rat-, and hamster lungs. In normal and injured lungs, PIMs exceed the number of PSMs (e.g. Thet et al., 1983).

Phenotypical and functional differences occur between the PIMs and the PSMs: PIMs are smaller in diameter (7.6 $\mu \mathrm{m}$ versus $16 \mu \mathrm{m}$ for the PSMs), are more homogenous in size, have a smoother outline [i.e., they have fewer and blunter filopodia (pseudopodia)], have an indented (kidney-shaped) nucleus and greater nuclear to cytoplasm ratio, the primary lysosomes and phagososmes are fewer and larger, mitochondria and rough (granular) endoplasmic reticulum are scanty, Golgi bodies are rare, the cells are less phagocytic, they possess greater antigen presenting capability to $\mathrm{T}$-cells, when they are activated they can release different cytokines [particularly TGF- $\beta$, TNF- $\alpha$, and metalloproteinases-1 (MCP-1) and IGF-1], and the cells resemble the peripheral monocytes (e.g. Kobzik et al., 1988; Sebring and Lehnert, 1992; Lavnikova et al., 1993; Wizemann and Laskin, 1994; Prokhorova et al., 1994; Johansson et al., 1997; Fathi et al., 2001). Antigenic differences occur between the PIMs and the PSMs (e.g. Kobzik et al., 1986). In the rat lung, regarding the mechanisms that are mainly involved in the induction and the furtherance of specific immune reactions, e.g., the major histocompartibility complex (MHC) class-II expression and interleukin (IL-1) and IL-6 production, the PIMs are more efficient than the PSMs (Steinmüller et al., 2000). Since they 


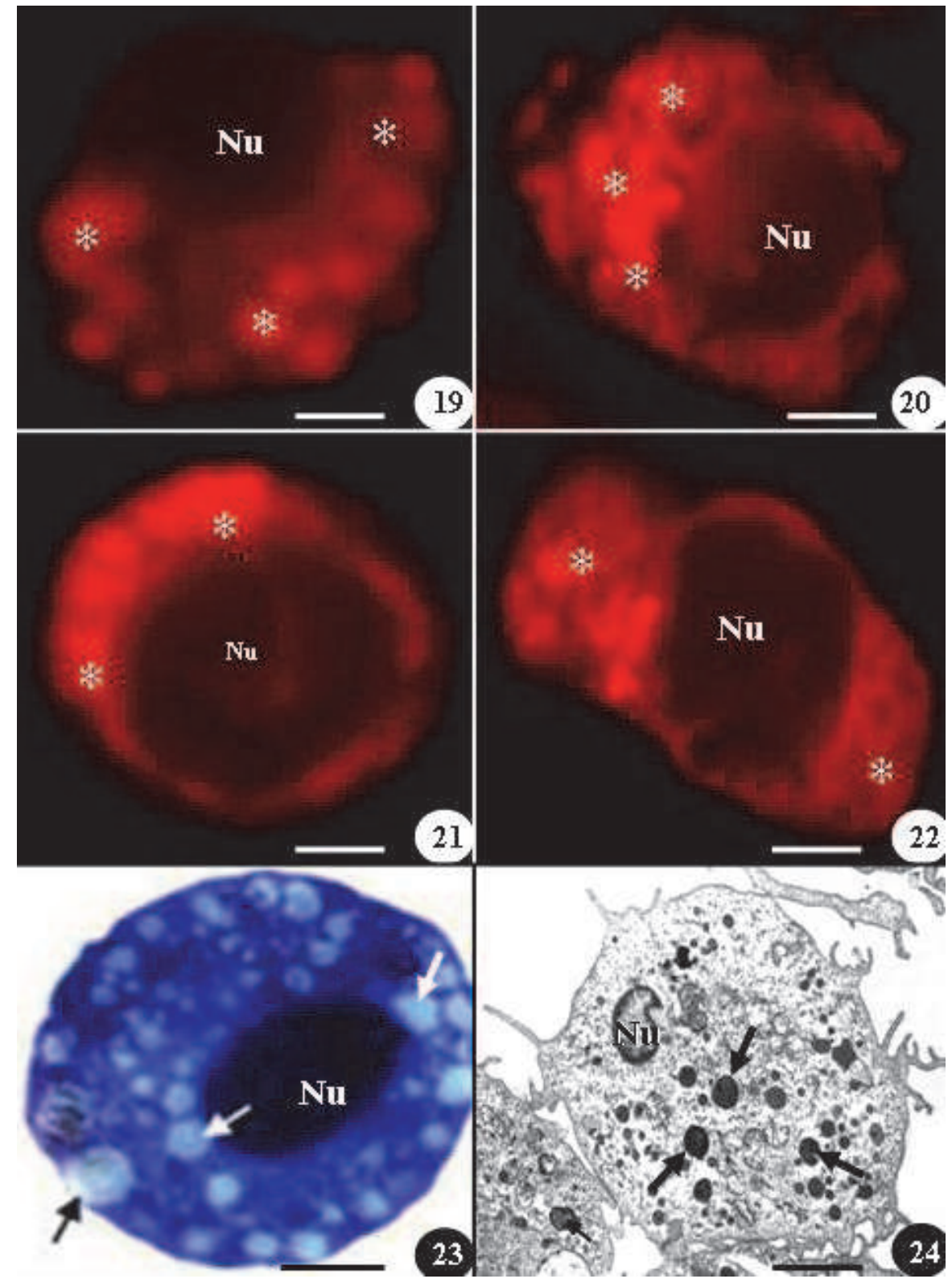

Fig. 19.-24. Pulmonary surface macrophages of the chicken (domestic fowl) (Gallus domesticus) showing the concentration of lyric vesicles in the cytoplasm in Figs. 19-22) (asterisks) and arrows (Figs. 23 and 24). Nu, nucleus. Scale bars: $4 \mu \mathrm{m}$. Figs. 19-22 from Nganpiep and Maina (2002) and Figs 23 and 24 from Kiama et al. (2008). 


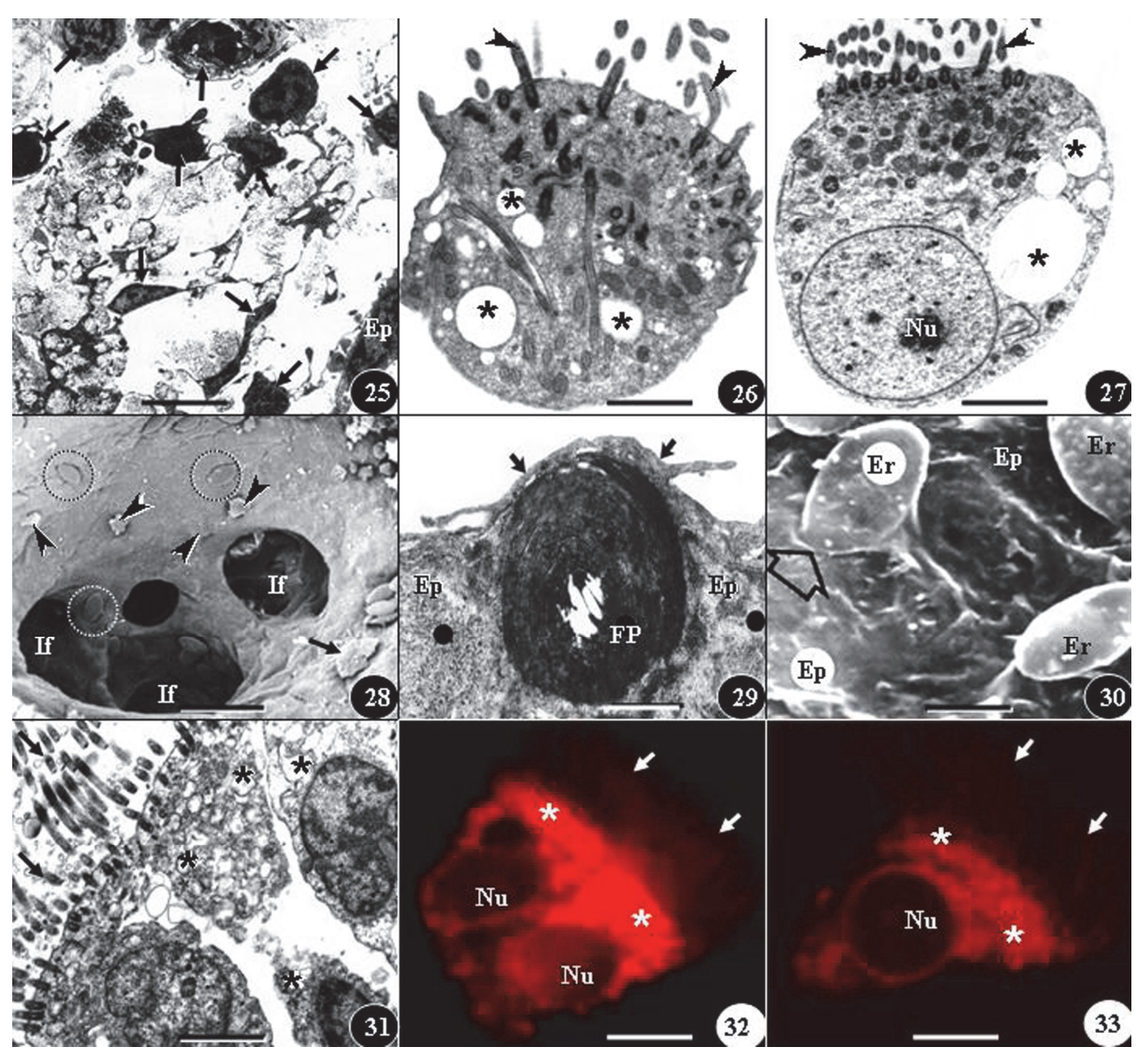

Fig. 25. Subepithelial macrophages in the lung of the chicken, Gallus domesticus (arrows). Ep, respiratory epithelium. Figs. 26 \& 27: Bronchial epithelial cells of the chicken's lung which have phagocytosed polysylene particles (stars). Arrow heads, cilia. Fig. 28: Surface of an atrium of a parabronchus of the lung of the chicken showing a surface macrophage (arrow), particles (arrow heads), and extravasated red blood cell (dashed circles) that are about to be phagocytosed by the epithelial cells. If, infundibulum. Fig. 29: Close-up of a foreign particle (FP) being engulfed by an epithelial cell (Ep) in the chicken lung. Arrows, cytoplasmic extensions of the epithelial cell. Fig. 30: Close-up of extravasated erythrocytes (Er) on the epithelial surface (Ep) of the lung of the duck, Cairina moschata. One of the erythrocytes (arrow) is being engulfed by the epithelial cell. Figs. 31-33: The ciliated bronchial epithelial cells (arrows) of the lung of the domestic fowl, Gallus gallus are well-endowed with lysosomes (stars). Nu, nuclei of the epithelial cells. Scale bars: Figs. 25, $50 \mu \mathrm{m} ; 26 \& 27,10$ $\mu \mathrm{m} ; 28,50 \mu \mathrm{m} ; 29,10 \mu \mathrm{m} ; 30,10 \mu \mathrm{m} ; 31-33,10 \mu \mathrm{m}$. From Nganpiep and Maina (2002).

are set in the lung tissue, the cytotoxic or inflammatory mediators released by the PIMs have greater biological and/or pathological effects on the surrounding lung tissue than those 
released by the PSMs (Steinmüller et al., 2000; Laskin et al., 2001). In the murine lung, PIMs exhibit immunoregulatory and phagocytic functions (e.g. Bilyk et al., 1988; Franke-Ullman et al., 1996). Increased numbers of PIMs appear within active lesions of the injured lung (e.g. Brain, 1988). There is ample evidence that PIMs replicate in situ (e.g. Bowden and Adamson, 1980). Compared to the PSMs, the PIMs exhibit a significantly greater proliferative capacity (Johansson et al., 1997), a process that maintains the lung macrophage pool in the lung tissue compartment (Adamson and Bowden, 1981).

The PIMs can be discriminated from the PSMs by their unique capacity of inhibiting the maturation of the lung's DCs and their migration on stimulation with lipopolysaccharides (LPS) like those located in the outer membrane of gram positive bacteria which act as endotoxins that elicit strong immune responses that prevent sensitization to prevailing antigens (e.g. Buckner and Finlay, 2011). In presence of LPS, PIMs and not PSMs disrupt the link between the innate and the adaptive immunity, allowing inhaled antigens to escape from T-cell dependent responses (e.g. Bedoret et al., 2009). The PIMs are morphologically more like the BMs than they are to PSMs (Sebring and Lehnert, 1992). It has been suggested by some investigators, e.g., Holt et al. (1982), Bluseé van Oud Alblas and van Furth (1982), and Sebring and Lehnert (1992) that PIMs are an intermediate maturation stage (from the bone marrow monocytes) of the PSMs, i.e., they are precursors of the PSMs before the cells transfer to the respiratory surface. There is, however, contrary evidence that PIMs represent a distinct population of cells with dedicated pulmonary inflammatory and immunoregulatory roles of defending the lung (e.g. Chandler et al., 1988; Dethloff and Lehnert, 1988; Lehnert, 1992; Prokhorova et al., 1994; Johansson et al., 1997; Zetterberg et al., 1998; Steinmüller et al., 2000). Although concerning inflammation and antimicrobial defense AMs exhibit greater functional repertoire related to and including increased chemotaxis, phagocytosis, cytotoxicity, and release of ROSs, PIMs express higher quantities of C3receptor and intercellular adhesion molecule-1 and are more active in producing interleukins-1 and -6 (IL-1 and -6) and exhibit greater I-a antigen expression (Chandler and Brannen, 1990; Franke-Ullmann et al., 1996; Steinmüller et al., 2000).

\section{Bronchial epithelial cells (BECs) and bronchial macrophages (BMs)}

The ciliated BECs and the nonciliated cells of the upper airways of the lung are the first cellular entities that interact and deal with the inhaled particulates and pathogenic microorganisms (Figs. 31-34). They secrete inflammatory cytokines that initiate and ultimately aggravate host innate inflammatory responses that may cause harmful immunemediated pathologies (e.g. Yoshikawa et al., 2010) and afterwards initiate remodelling of the lung (Altraja et al., 2009). In the bronchial tree, macrophages are suspended in the mucus carpet while others lie under the layer, directly attached onto the epithelial substratum (e.g. Sorokin and Brain, 1975; Brain et al., 1984; von Garnier and Nicod, 2009) (Fig. 34). A highly active group of cells, ciliated BECs and non-ciliated BECs may ingest and degrade antigens that land on the surface of the airways and/or may release mediators that attract lymphocytes, neutrophils, or mast cells to the airways and regulate their activities there (Geiser et al., 1988). On their depositing on the airway epithelium, inhaled bacteria soon loose their replicative capacity (e.g. Laurenzi et al., 1964; Brain et al., 1984). Particulates with a diameter of less than $10 \mu \mathrm{m}\left(\mathrm{PM}_{10}\right)$ stimulate epithelial cells to produce ROS and inflammatory mediators/cytokines (Carter et al., 1997; Fujii et al., 2001; Schaumann et al., 
2004; Ishii et al., 2005). In the avian lung, ciliated epithelial cells particularly phagocytose inhaled atmospheric particles (Fedde, 1997; Maina and Cowley, 1998; Fujii et al., 2001; Nganpiep and Maina, 2002) (Figs. 26, 27). Ciliated BECs express an oxidative stress response that is different from that of the PSMs by rapidly shifting from cytoprotective to cytotoxic responses but are incapable of converting $N$-acetylcysteine to cytoprotective glutathione ( $\mathrm{Li}$ et al., 2002). A mucus escalator system, which is maintained by the motility of cilia (Fig. 34), transports particulates and pathogens that settle on the airways towards the mouth. Normal motility of cilia is vital to the preservation of the integrity of the mucus conveyer-belt system. Infectious diseases and genetic conditions that reduce or abolish cilia motility, e.g., Kartagener's syndrome (e.g. Mahsud and Din, 2006; Kapur et al., 2009), and those that increase the consistency (viscosity) of the mucus, e.g., cystic fibrosis (Chmiel and Davis, 2003; McShane et al., 2004) lead to higher incidence of pulmonary infections, as they decrease the removal of particulates and pathogens by the mucus escalator system.
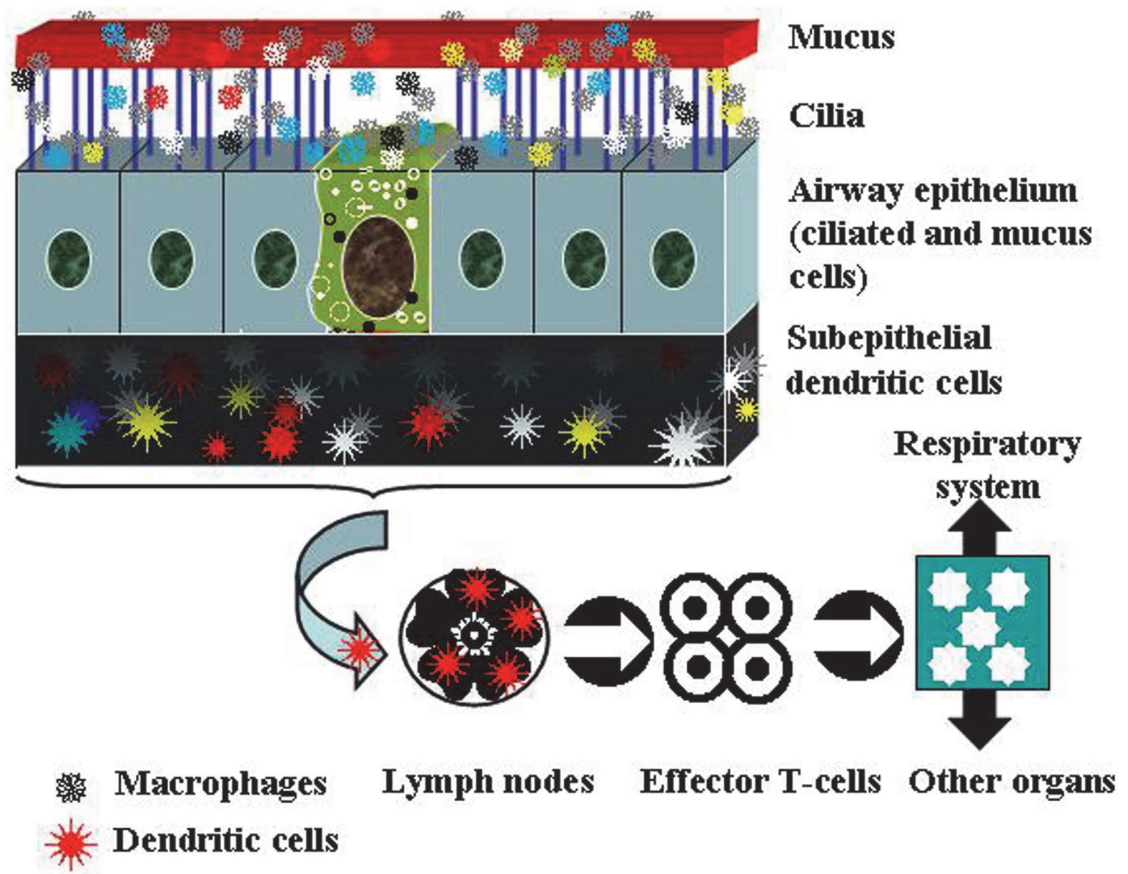

Fig. 34. Schematic diagram of the bronchial epithelium. Bronchial macrophages are located in the mucus carpet and on the epithelial cells themselves. Dendritic cells are located in the subepithelial space from where they send their long projections between the epithelial cells to sense foreign agents.

According to Fireman et al. (1999), 'asthma may be defined as failure to regulate T-cell mediated immunoreactivity within the bronchial wall of hyperreactive airways'. Inadequate regulation of the T-cell response by suppressive macrophages may set off allergic bronchial inflammation. The BMs of asthmatics are functionally modulated (e.g. Fireman et al., 1999: 
they have lower suppressive activity. Probably caused by T-helper cell cytokines (Th-2), this explains the bronchial hyperactivity displayed by asthmatics (Fireman et al., 1999; Alexis et al., 2001). Different subsets of the BMs may to different extents regulate the inflammatory response in allergic asthma and respond to immunomodulatory signals, especially those mediated by interleukin 10 (IL-10) (Moniuszko et al., 2007). Power et al. (1994) observed that in normal human bronchial wall, a small number of T-cells, the majority of which were $\mathrm{CD}^{+}$cells existed: $\mathrm{CD} 4^{+}$cells predominated in the subepithelial tissue and a small number of macrophages were present. In individuals with sarcoidosis, compared to healthy subjects, Hawley et al. (1979) observed physical interaction between the BMs and the lymphocytes, the BMs presented a more highly irregular cell surface, and more membrane bound inclusions and fewer lysosomes and phagolysosomes were present: no significant differences were observed in the nuclear or cellular diameters of the BMs from normal- and sarcoidosis affected individuals. In patients with chronic obstructive pulmonary disease (COPD), the BMs were relatively small in size, contained little cytoplasm, and had a markedly high kario-cytoplasmic ratio (Fedosenko et al., 2010): these features improved after treatment with the drug tiotropium. In the bronchial mucosa of patients with chronic bronchitis, there was a significant number of BMs and T-lymphocytes in the lamina propria (Saetta et al., 1993): these cells may be involved in the pathogenesis of the disease.

\section{Dendritic cells (DCs)}

The DCs derive from bone marrow precursor cells and with their maturation, dependent on the extracellular microenvironments establish themselves as immature cells in tissues (e.g. Steinman, 1991; Reid, 1997; Hart, 1997; Banchereau and Steinman, 1998; Austyn 1998; Satthaporn and Eremin, 2001; Lipscomb and Masten, 2002; Geurtsvankessel and Lambrecht, 2008; Fries and Griebel, 2011). Under appropriate signals, monocytes can differentiate into DCs (e.g. Banchereau and Steinman, 1998; Satthaporn and Eremin, 2001) which are potent antigen uptake, processing, and presenting cells (e.g. Belz et al., 2004; Harada et al., 2009; Bedoret et al., 2009). Highly specialized and notably heterogenous, DCs function as messengers and regulators between innate and acquired immunity (e.g. Reid, 1997; Hart, 1997; Banchereau and Steinman, 1998; Austyn, 1998; Satthaporn and Eremin, 2001; Dzionek et al., 2000; Webb et al., 2005; McKenna et al., 2005; Lommatzsch et al., 2007, 2010; GeurtsvanKessel and Lambrecht, 2008; von Garnier and Nicod, 2009). Because DCs have the ability to induce a primary immune response in resting naïve T-lymphocytes and play a role in the maintenance of B-cell function and antigen memory (recall) responses (e.g. Webb et al., 2005; Bessa et al., 2009), they were called 'professional antigen presenting cells' by, e.g., Lipscomb and Masten (2002) and Liu (2005). To better assess incoming antigens for possible threat, mature DCs particularly occur in tissues that interface between the external- and the internal environments and are therefore greatly exposed to microbial pathogens, harmful particulates, and injurious gases. These include the skin, where the cells are called Langerhan's cells [named after Paul Langerhan (1847-1888), a German physician, who first described them in the late 19th Century], the inner lining of the nose, the lungs, the stomach, and the intestines (e.g. Satthaporn and Eremin, 2001; Sallusto and Lanzavecchia, 2002; von Garnier and Nicod, 2009). Notable exceptions are the complete absence of the DCs in the cornea and the central nervous system (e.g. Steinman, 1991). DCs are a major source of many cytokines, e.g., interferon- $\alpha$ (IFN- $\alpha$ ) and the inflammatory protein MIP1g: both of these molecular factors are important in effecting primary immune response (e.g. Zhou and 
Tedder, 1995; Devergne, 1996). In the different sites where they are located, DCs differentiate and become active in acquiring and processing antigens. The subsequent presentation on the host cell surface is associated with the major histocompatibility molecules (e.g. Meyer and Mack, 2003).

The DCs are found in immature form in blood (e.g. Dzionek et al., 2000) (Fig. 35) and once they are activated, they migrate to the lymph nodes where they interact with the T- and Bcells to initiate acquired immune response. In the lung, DCs exist in many subpopulations that are fine-tuned to different roles that maintain immune homeostasis. Infectious and inflammatory conditions can profoundly change functions, with steady-state DC subsets resulting in recruitment of inflammatory type DCs (e.g. Geurtsvankessel and Lambrecht, 2008) which exert specific functions that can be associated with distinct expression of endocytotic receptors and cell-surface molecules, and the topographical location in the lung. During DC trafficking into the lung, blood DCs are preferentially recruited over blood monocytes (Klinke, 2006): for short-lived antigens, lung epithelial DCs that are derived from blood DCs exhibit a $62.5 \%$ increase in antigen density compared to those derived from the blood monocytes. The cells (DCs) are located within the bronchial epithelium and the pulmonary interstitium where they impinge on the innate immune system. CD11c-positive DCs are widely distributed in the alveolar region of the lung, with most of them displaying an immature phenotype (Gonzalez-Juarrero and Orme, 2001): the cells are capable of phagocytosing live Mycobacterium tuberculosis bacteria, leading to secretion of interleukin-12 (IL-12) and stimulation of CD4-T cells to produce gamma interferon (IFN- $\gamma$ ). In steady-state (homeostatic) conditions, fine balance exists between the various functions of lung's DC populations, a feature necessary for the maintaintence of immune homeostasis in the lung (GeurtsvanKessel and Lambrecht, 2008). On identification and internalization of pathogens, DCs move to the draining lymph nodes of the lung to instigate specific cellular and humoral immune responses. Extensive network of bone marrow-derived DCs exist in the mucosa of the nose and the large conducting airways, the alveolar lumen, and the connective tissue surrounding the blood vessels and the pleura (Holt et al., 1988, 1994; Schon-Hegrad et al., 1991; van Haarst et al., 1994; Lambrecht et al., 1998; Gonzalez-Juarrero and Orme, 2001; von Garnier and Nicod, 2009). The migration of the airway DCs in response to an immunogenic stimulus is rapid (e.g. Havenith et al., 1993; Xia et al., 1995): within 12 hours, the lung derived DCs can be found in the T-cell area of draining mediastinal lymph nodes of the lung. Inflammatory diseases of the human lung are associated with the different phenotypes and the process of the recruitment of the airway DCs (Lommatzsch et al., 2007, 2010; Geurtsvankessel and Lambrecht, 2008; Vassallo et al., 2010). Regulation of galectin-3 in the lungs may represent one of the multiple potential mechanisms by which galectins contribute to modulation of the innate and acquired immune responses (Maldonado et al., 2011).

The classical morphology of the DCs, i.e., that of having numerous membranous processes (projections) that extend out of the main cell body (Fig. 35), makes them highly motile. Also, it endows them with very large surface-to-volume ratio that permits them to contact and therefore adeptly sample (sense) vast parts of the surrounding environment. DCs contain abundant antigen processing organelles that include endosomes, lysosomes, and special granules. From their distinctive projections, the designation 'dendritic cell' was coined by Steinman and Cohn (1973) since the cells (DCs) resemble the dendrites of the neurones, although DCs are not associated with the nervous system and by extension the neuronal dendrites. 


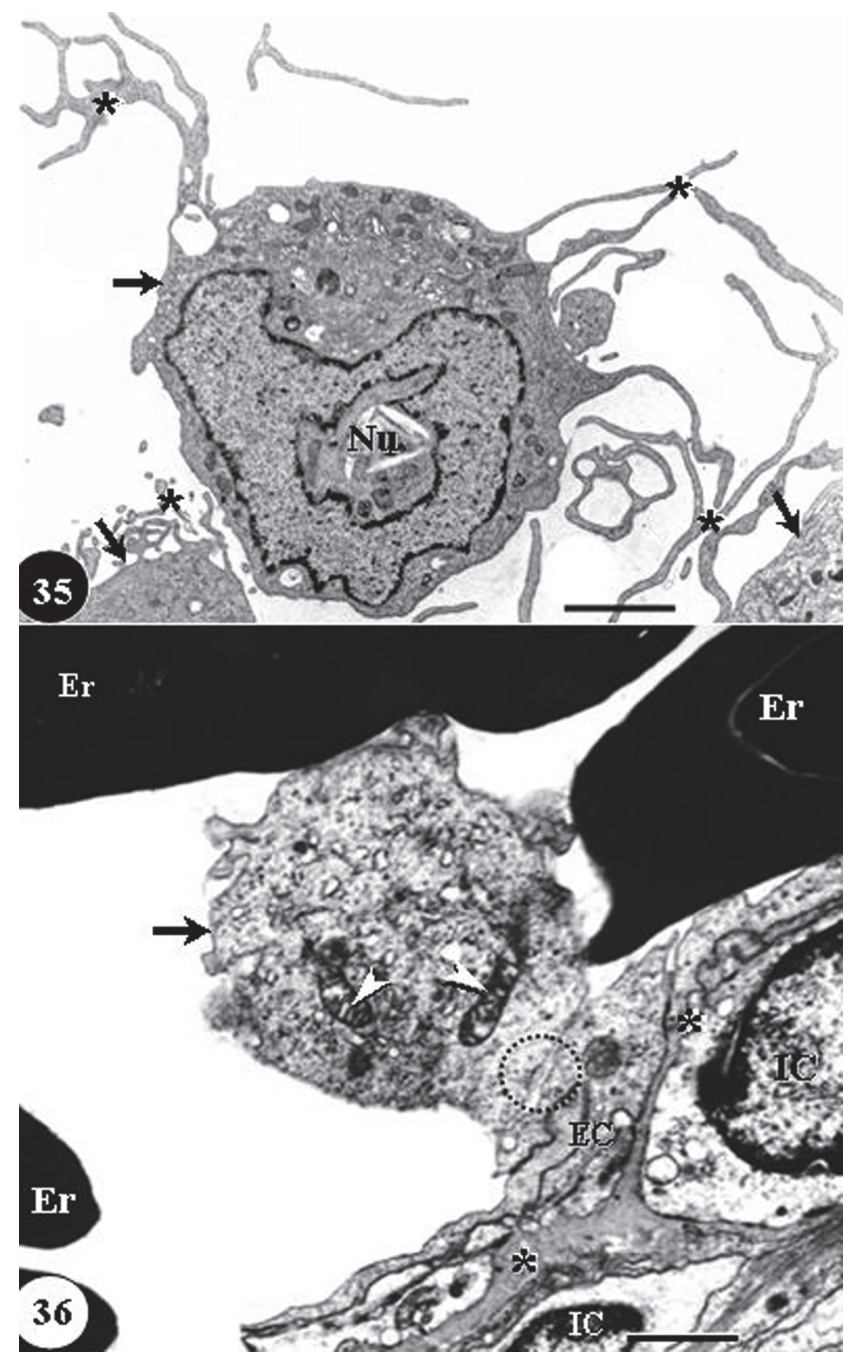

Fig. 35. Dendritic cells from the peripheral blood (arrows) showing cytoplasmic extensions (stars) that the cells use to move and sense the surrounding environment. Nu, nucleus. Courtesy of Dr. S.G. Kiama, University Nairobi, Kenya. Fig. 36: A pulmonary intravascular macrophage (arrow) in the lung of the rock dove, Columba livia, attached to the vascular endothelial cell (dashed circle). EC, endothelial cell; Er, erythrocyte; asterisk, basement membrane; arrow heads, mitochondria; IC, interstitial cells. Scale bars: Fig. 35, $15 \mu \mathrm{m}$; $36,10 \mu \mathrm{m}$.

Depending on species, DCs are classified into myeloid DCs (mDCs) and plasmacytoid DCs (pDCs) (e.g. McKenna et al., 2005; Geurtsvankessel and Lambrecht, 2008; von Garnier and Nicod, 2009). The former are more common and are divided into an mDC-1 subpopulation which is the foremost stimulator of T-cells and the mDC-2 which are involved in wound 
healing. Both groups of cells secrete IL-12 (interleukin-12) and express TLR-2 and TLR-4 receptors (e.g. Sallusto and Lanzavecchia, 2002). The pDCs resemble plasma cells but have certain features similar to the mDCs (Vanbervliet et al., 2003; Liu, 2005): they can produce large amounts of interferon- $\alpha$. The functional specialization and the degree of maturation of the DCs are determined by the tissue environment and the tissue cells that DCs directly interact with (Wu and Liu, 2007). In the airways, DCs sense incoming airborne antigens by extending their dendrites through the epithelial cells that line the airway lumen (e.g. Jahnsen et al., 2006; Holt et al., 2008). Under normal (healthy = steady-state) conditions, in the alveolar space, $80 \%$ of the cells are PSMs, with the remainder comprising of T-cells and DCs (von Garnier et al., 2005). In the respiratory tract, resident DCs are deemed to be immature (von Garnier and Nicod, 2009). This signifies that the cells have optimal capacity of detecting, capturing, and processing inhaled antigens but have a low capacity of stimulating T-cells. In contrast to the B and T-lymphocytes, DCs have retained many of the pattern recognition receptors and are thus uniquely capable of sensing stimuli such as tissue damage, necrosis, and bacterial and viral infection (Webb et al., 2005; Klinke, 2006). The capacity of the lung's DCs to influence specific CD-4 and CD-8 T-lymphocytes makes them suitable candidates for vaccine development strategies for treating and preventing conditions and diseases such as allograft rejection responses, allergy, and asthma, as well as autoimmune diseases and cancers (Fong and Engelman, 2000; Syme and Gluck, 2001; Sharma et al., 2003; Schott and Seissler, 2003; Decker et al., 2006; Sbiera et al., 2008).

\section{Pleural macrophages (PIMs)}

The PIMs are one of the pulmonary macrophage cell lineages that have been least studied (e.g. Brain 1992). Lehnert (1992) suggested that PlMs originate from peripheral blood monocytes that migrate across the mesothelial lining of the pleura. Meuret et al. (1980), Zlotnik et al. (1982) and Sestini et al. (1984) observed that PIMs were more morphologically similar to the peritoneal macrophages than to the PSMs. This may be attributed to the prevailing similarities and differences in the prevailing microenvironments (Brain, 1992) like the variation in the $\mathrm{PO}_{2}$ (Brain 1988). Frankenberger et al. (2000) noted that PIMs are a unique kind of tissue macrophage. Under normal physiological conditions, the pleural cavity is in a state of negative (subatmospheric) pressure: low oxygen $\left(\mathrm{O}_{2}\right)$ tension $\left(\mathrm{PO}_{2}\right)$ prevails in it. Pleural $\mathrm{O}_{2}$ exposure induces oxidative injury and aggravates latent systemic inflammatory response (Tsukioka et al., 2007). Resident PIMs sense perturbations in the local environment and initiate neutrophil infiltration (Cailheir et al., 2006). The drugs carrageenan and tetracycline prompt dramatic increase in PIMs (e.g. Sahn and Potts, 1978; Ackerman et al., 1980; Strange et al., 1989; Baumann et al., 1993) by recruiting monocytes from the peripheral circulation (Antony et al., 1985). In vivo experiments have demonstrated tumoricidal- (Basic et al., 1979; Nagashima et al., 1987), phagocytic- (Meuret et al., 1980; Zlotnik et al., 1982; Zlotnik and Crowle, 1982), and antimicrobial activities of the PIMs (Meuret et al., 1980; Hammerstrom, 1980; Zlotnik and Crowle, 1982). Compared to PSMs, the cells (PIMs) release prostaglandins E-1 and E-2 and respond differently to various cytokines (Sestini et al., 1984; Nagashima et al., 1987).

Agostini et al. (1972) suggested that PlMs may function as roller bearings that allow smooth movement between the parietal- and the visceral pleura. The PIMs seem to be functionally important in both health and disease (Zlotnik et al., 1982; Zlotnik and Crowle, 1982). 
Morphologically, a normal resident PIM has prominent intermediate intracytoplasmic filaments and numerous microvilli that may be involved in the adherence to the pleural surfaces (Baumann et al., 1993). From assessment of the uptake of latex beads, the phagocytic capacity of the PIMs is lower than that of the bronchoalveolar mononuclear phagocytes (BAMP) (that comprise of the BMs and the PSMs) and when cultured together with autologous pulmonary interstitial DCs, PIMs exert a more potent ability to stimulate Tcell proliferation than the BAMPs (Gjomarkaj et al., 1999). Compared to the BAMPs, PIMs are less portent bactericidal and fungicidal cells (Gjomarkaj et al., 1999): functionally and phenotypically PIMs are different from the BAMPs and are similar to the peritoneal macrophages. PIMs play an important role in cell-mediated immune reactions in the pleural space (Gjomarkaj et al., 1999). Compared to the blood monocytes, PIMs seem to represent a cell-type intermediate between the regular CD-14(++) monocytes and the CD-14(+)CD-16(+) subset (Frankenberger et al., 2000). PIMs perform efficient Fc-receptor-mediated phagocytosis of antibody-coated sheep red blood cells and can inhibit apoptosis of malignant cells (Kaczmarek et al., 2008).

\section{Pulmonary intravascular macrophages (PIVMs)}

For the reasons that the PIMs are lacking in the lungs of most laboratory animals (e.g. Warner and Brain 1990; Warner, 1996; Brain et al., 1999) and since they are relatively less accessible for experimentation, the cells have not been as well-studied as the PSMs. Regarding their secretory, endolytic, and functional properties, PIVMs are a relatively newly identified constituent of the mononuclear phagocyte system. To date, for still unclear reasons, PIVMs have been reported mainly in the domestic mammals, especially in ruminant species like cattle, horse, goat, sheep, and pigs (e.g. Rybicka et al., 1974; Warner and Brain, 1984; Atwal and Saldanha, 1985; Wheeldon and Hansen-Flaschen, 1986; Warner et al., 1986; Winkler, 1988, 1989; Atwal et al., 1989, 1992; Warner and Brain, 1990; Longworth et al., 1994; Warner, 1996; Parbhakar et al., 2005; Molina and Brain, 2007) and in birds (Maina and Cowley, 1998) (Fig. 36). It is uncertain whether PIVMs occur in the human lung: while the cells were reported by Dehring and Wismar (1989), a comprehensive morphometric study of the human lung by Zeltner et al. (1987) didn't report macrophage or macrophagelike cells in the pulmonary capillaries. Particle uptake studies suggested that PIVMs may not exist in the human lung (e.g. Brain et al., 1999).

The PIVMs have distinctive morphological features of differentiated macrophages like irregular shape, a bean-shaped nucleus, abundant lysosomal bodies, numerous mitochondria, profuse rough endoplasmic reticulum, fuzzy glycocalyx, phagosomes, and pseudopods (e.g. Wheeldon and Hansen-Flaschen, 1986; Warner et al., 1986; Winkler and Cheville, 1985, 1987). They have an electron dense coat that appears to be predominantly lipoproteinaceous in nature (Atwal et al., 1989). PIVMs form membrane adhesion complexes with the endothelial cells (Warner et al., 1986; Winkler and Cheville, 1987) and tend to attach onto the thicker parts of the BGB (Winkler, 1988; Winkler and Cheville, 1987), probably minimizing interference with gas exchange (by thickening the BGB) which occurs mostly across the thin parts. Moreover, it is possible that the thicker parts of the BGB provide better support than the thinner ones, preventing the cells from being easily dislodged by flowing blood. PIVMs are large in size (20 to $80 \mu \mathrm{m}$ in diameter), are closely apposed to the endothelium of the pulmonary blood capillaries (Wheeldon and Hansen-Flaschen, 1986; 
Brain et al., 1999), and are abundantly endowed with organelles like vesicles, endosomes, and Golgi apparatus (e.g. Atwal et al., 1992) (Fig. 36). The PIVMs form an important part of the defence of the vertebrate lung. In the pig, perinatally, in a process that is completed by the $7_{\text {th }}$ day of birth, blood monocytes colonize the lung, replicate within the blood capillaries, and attach to the endothelium by intercellular junctions as they differentiate (Winkler and Cheville, 1985). By actively synthesizing, storing, and secreting vasoactive substances, PIVMs stimulate biosynthetic pathways that lead to secretion of inflammatory mediators which compound certain disease processes (e.g. Brain, 1986; Kelly, 1990). They actively remove particles, bacteria, and endotoxins from circulating blood (Wheeldon and Hansen-Flaschen, 1986; Warner and Brain, 1986; Warner et al., 1986; Winkler, 1989; Brain et al., 1999). While in dogs, laboratory animals, and human beings, clearance of bacteria and particulates from blood occurs mainly in the Kupffer cells of the liver and the splenic macrophages, in calves, sheep, goats, cats, and pigs, the process is performed by the PIVMs (e.g. Warner et al., 1987; Winkler, 1988; Brain et al., 1999). In the sheep lung, PIVMs form $15.3 \%$ of the intravascular volume, attach onto $7.1 \%$ of the endothelial surface, and have 15.9 $\mathrm{m}^{2}$ of their free surface available for contact with blood (Warner et al., 1986). Even in normal (steady-state) sheep lungs, there are more macrophages in their vast pulmonary blood vessels than on their alveolar surface and compared to the PSMs the PIVMs are relatively more actively phagocytic (Warner et al., 1986). In the deer, PIVMs are more than twice the number of PSMs but PIVMs are much smaller $\left(47.625 \mathrm{~m}^{2}\right)$ than the PSMs $\left(101.260 \mathrm{~m}^{2}\right)$ (Carrasco et al., 1996).

The PIVMs have been implicated in the vascular inflammation that results in lipopolysaccharide (LPS)-induced lung inflammation and endotoxemia in the horse (Aharonson-Raz and Singh, 2010), rat (Gill et al., 2008), and sheep (Warner et al., 1986, 1987) and with the oedema that occurs in the horse after infection with the African horse sickness virus (Carrasco et al., 1999). While in the newborn pig clearance of blood-borne bacteria (as well as carbon) is only $\sim 10 \%$ of the injected dose (Mouton et al., 1963), in pigs of 15 to $20 \mathrm{~kg}$ body mass ( 20-month old), 75\% of intravenously infused bacteria (depending on species of bacteria) are cleared in the lungs (Wismar et al., 1984; Dehring et al., 1983). PIVMs play a significant role in regulating pulmonary blood flow, i.e., hemodynamics (e.g. Winkler 1989): stimulation of phagocytosis causes the PIVMs to increase in size thus narrowing or blocking the lumina of blood vessels (Winkler and Cheville, 1985). In pigs as well as calves and sheep, this increases resistance to blood flow, leading to pulmonary hypertension (Tucker et al., 1975; Atwal et al., 1989) and pulmonary oedema (Niehaus et al., 1980). Bovine PIVMs contain TNF-a (tumour necrotic factor) and their depletion significantly inhibits accumulation of inflammatory cells and pathology in acute lung disease in calves (Singh et al., 2004). In ruminants, PIVMs are involved in lipid metabolism and are the major source of vasoactive substances which significantly influence the dynamics of pulmonary circulation and surfactant turn over in the type-2 cells (Atwal et al., 1989).

\section{Conclusion and future directions}

Although substantial progress has been made in understanding the physical and functional phenotypes of macrophages in the lung, the knowledge remains scanty. This is evinced by lack of significant breakthroughs in the management and treatment of diseases like acute respiratory distress syndrome (ARDS). Furthermore, the specific functions performed by the 
different pulmonary macrophage lineages and the manner in which these cells communicate remain unclear.

Animals have evolved in close association with microorganisms some of which are harmful: intense selective pressure by the pathogens on the animal hosts and vice-versa has and continues to happen. In a critical encounter, when a pathogen contacts a host, a struggle between it and the host ensues. The outcome is infection and blatant disease or the pathogen is neutralized and eliminated. Successful microbial pathogens have been adept in developing means and strategies of evading the host defences while successful hosts have developed novel defence systems. Understanding the underpinnings behind the evolution of microbial pathogenicity and the intricate ways that animals counteract pathogens is vital in designing strategies of controlling microbial infection and stopping disease progression. Few other organs in the body are as well- and strategically protected as the lung: a cellular defence arsenal exists. From outside to inside are the pleural-, the intravascular, the interstitial-, and the surface (free) macrophages and along the airways (bronchi) are the bronchial macrophages, the dendritic cells, and the epithelial cells. This intricate level of protection has mainly developed because of the vast respiratory surface area that is constantly ventilated with air (which depending on locality contains harmful particulates and pathogenic microorganisms) and the fact that the lung is the only organ in the body which is perfused by the entire cardiac output, a feature that places it at greater risk from blood borne injurious agents. The biology of phagocytes and antigen presenting cells should provide insights on the pathogenesis of pulmonary diseases and may explain why some diseases, including the zoonotic ones, affect certain animal species and groups and not others. Important as it is, the area of comparative immunology offers much to be investigated.

\section{Acknowledgment}

I wish to thank the following colleagues who collaborated with me in the work that forms part of this contribution. These are: H. Cowley, L. Nganpiep, J. S. Adekunle, and S.G. Kiama. The National Research Foundation (NRF) funded this work.

\section{References}

Ackerman N, Tomolonis A, Miran L, Kheifets J, Martinez S, Carter A (1980) Three day pleural inflammation: a new model to detect drug effects on macrophage accumulation. J. Pharmacol. Exp. Ther. 215:588-595.

Adamson I, Bowden D (1981) Dose response of the pulmonary macrophagic system to various particulates and its relationship to transepithelial passage of free particles. Exp. Lung Res. 2:165-175.

Agostini E (1972) Mechanics of the pleural space. Physiol. Rev. 52:57-128.

Aharonson-Raz K, Singh B (2010) Pulmonary intravascular macrophages and endotoxininduced pulmonary pathophysiology in horses. Can. J. Vet. Res. 74:45-49.

Alexis NE, Soukup J, Nierkens S, Becker S (2001) Association between airway hyperactivity and bronchial macrophage dysfunction in individuals with mild asthma. Am.J. Physiol. Lung Cell Mol Physiol. 280:L369-L375. 
Alexis NE, Lay JC, Zeman KL, Geiser M, Kapp N, Bennett WD (2006) In vivo particle uptake by airway macrophages in healthy volunteers. Am. J. Respir. Cell Mol. Biol. 34:305313.

Altraja S, Jaama J, Valk E, Altraja A (2009) Changes in the proteome of human bronchial epithelial cells following stimulation with leukotriene E4 and transforming growth factor-beta1. Respirology 14:39-45.

Antony VB, Sahn SA, Antony AC, Repine JE (1985) Bacillus-calmette-guerin-stimulated neutrophils release chemotaxins for monocytes in rabbit pleural spaces and in vitro. Clin. Invest. 76:1514-1521.

Apanius V, Penn D, Slev PR, Ruff LR, Potts WK (1997) The nature of selection on the major histocompatibility complex. Crit. Rev. Immun. 17:179-224.

Atwal O, Minhas K, Ferenczy B, Jassal D, Milton D, Mahadevappa V (1989) Morphology of pulmonary intravascular macrophages (PIMs) in ruminants: ultrastructural and cytochemical behaviour of dense surface coat. Am. J. Anat. 186:285-299.

Atwal OS, Saldanha KA (1985) Erythrophagocytosis in alveolar capillaries of goat lung: ultrastructural properties of blood monocytes. Acta Anat. 124:245-254.

Atwal OS, Singh B, Staempfli H, Minhas KJ (1992) Presence of pulmonary intravascular macrophages in the equine lung: some structural-functional properties. Anat. Rec. 234:530-540.

Austyn JM (1998) Dendritic cells. Curr. Opin. Hematol. 5:3-15.

Banchereau J, Steinman RM (1998) Dendritic cells and the control of immunity. Nature 392:245-252.

Bargmann W (1936) Die Lungenalveole. In: Handbuch der mikroskopischen Anatomie des Menschen (Möllendorf W ed). Springer, Berlin, pp. 799-859.

Baron S, Tyring ST, Fleischmann RW, Coppernhaver DH, Niesel DW et al. (1991) The interferons: mechanisms of action and clinical applications. JAMA 266:1375-1383.

Bartl S, Baltimore D, Weissman IL (1994) Molecular evolution of the vertebrate immune system. Proc. Natl. Acad. Sci, USA 91:10769-10770.

Basic I, Rode B, Kastelan A, Milas L (1979) Activation of pleural macrophages by intrapleural application of Corynebacterium parvam. In: Advances in experimental medical biology, vol. 121(A) (Escobar MR, Friedman H, eds). Plenum, New York, pp. 333-341.

Baumann MH, Heinrich K, Sahn SA, Green C, Harley R, Strange C (1993) Electron microscopic analysis of the normal and the activated pleural macrophage. Exp. Lung Res. 19:31-742.

Beck G, Habicht GS (1991) Primitive cytokines: harbingers of vertebrate defense. Immun. Today 3:180- 183.

Beck G, Habicht GS (1996) Immunity and the invertebrates. Sci. Amer. 1996:60-66.

Beck G, Cooper EL, Habicht GS, Marchalonis JJ (eds) (1994) Primordial immunity: foundations for the vertebrate immune system. Ann. NY Acad. Sci. 712:57-84.

Bedoret D, Wallemacq H, Marichal T, Desmet C, Calvo FQ, Henry E et al. (2009) Lung interstitial macrophages alter dendritic cell functions to prevent airway allergy in mice. J. Clin. Invest. 119:3723-3738.

Bellavite P, Dri P, Bisiachi B, Patricia P (1977) Catalase deficiency in myeloperoxidase deficient polymorphonuclear leukocytes from chicken. Fed. Exp. Biol. Soc. Lets. 81:73-76 
Belz GT, Smith CM, Kleinert L, Reading P, Brooks A et al. (2004) Distinct migrating and nonmigrating dendritic cell populations are involved in MHC class 1-restricted antigen presentation after lung infection with virus. PNAS 101:8670-8675.

Bessa J, Jegerlehner A, Hinton HJ, Pumpens P, Saudan P et al. (2009) Alveolar macrophages and lungdendritic cells sense RNA and drive mucosal IgA responses. J. Immun. 183:3788-3799.

Bezuidenhout AJ, Groenewald HB, Soley JT (2000) An anatomical study of the respiratory air sacs in ostriches. Onderstpoot J. Vet. Res. 66:317-325.

Bilyk N, Mackenzie JS, Papadimitriou JM, Holt PG (1988) Functional studies on macrophage populations in the airways and the lung wall of SPF mice in the steady-state and during respiratory virus infection. Immunology 65:417-425.

Biswas SK, Sica A, Lewis CE (2008) Plasticity of macrophage function during tumour progression: regulation by distinct molecular mechanisms. J. Immun. 180:2011-2017.

Blum G, Falbo V, Caprioli A, Hacker J (1995) Gene clusters encoding the cytotoxic necrotizing factor type 1 , Prs-fimbriae and alpha-hemolysin form the pathogenicity island II of the uropathogenic Escherichia coli strain 96. FEMS Microbiol. Lett. 126:189-195.

Blum G, Ott M, Lischewski A, Ritter A, Imrich H et al. (1994) Excision of large DNA regions termed pathogenicity islands from tRNA-specific loci in the chromosome of an Escherichia coli wild- type pathogen. Infect. Immun. 62:606-614.

Blussé van Oud Alblas A, Mattie H, van Furth R (1983) A quantitative evaluation of pulmonary macrophage kinetics. Cell Tissue Res. 16:211-219.

Blussé van Oud Alblas A, van Furth R (1979) Origin, kinetics, and characteristics of pulmonary macrophages in the normal steady state. J. Exp. Med. 149:1504-1527.

Boman HG, Hultmark D (1987) Cell-free immunity in insects. Annu. Rev. Microbiol. 41:103126.

Bowden DH (1976) The pulmonary macrophage. Environ. Health Perspect. 16:55-60.

Bowden DH (1987) Macrophages, dust, and pulmonary disease. Exp. Lung Res. 12:89-107.

Bowden DH, Adamson IYR (1980) Role of monocytes and interstitial cells in the generation of alveolar macrophages, I: kinetic studies in normal mice. Lab. Invest. 42:511-517.

Brahmbhatt M (2005) Avian and human pandemic influenza: economic and social impacts. WHO Headquarters, Geneva, November Issue, pp. 7-9.

Brain JD (1971) The effects of increased particles on the number of alveolar macrophages. In: Inhaled particles III, vol. 1 (Walton WH ed). Unwin Bros., Surrey, pp. 209-225.

Brain JD (1976) The pulmonary macrophage. Environ. Health Perspect. 16:55-60.

Brain JD (1980) Pulmonary macrophages and the pathogenesis of lung diseases. Environ. Health Perspect. 35:2-28.

Brain JD (1984) The alveolar macrophage. Environ. Health Perspect. 55:327-341.

Brain JD (1986) Toxicological aspects of alterations of pulmonary macrophage function. Annu. Rev. Pharmacol. Toxicol. 26:547-565.

Brain JD (1987) Macrophages, dust, and pulmonary diseases. Exp. Lung Res. 12:89-107.

Brain JD (1988) Lung macrophages: how many kinds are there? What do they do? Am. Rev. Respir. Dis. 137:507-509.

Brain JD (1992) Mechanisms, measurement, and significance of lung macrophage function. Environ. Health Perspect. 97:5-10.

Brain JD (1996) Environmental lung disease: exposure and mechanisms. Chest 109:74-78. 
Brain JD, Gehr P, Kavet RI (1984) Airway macrophages: the importance of the fixation method. Am. Rev. Respir. Dis. 129:823-826.

Brain JD, Molina RM, DeCamp MM, Warner AE (1999) Pulmonary intravascular macrophages: their contribution to the mononuclear phagocyte system in 13 species. Am. J. Physiol. (Lung Cell Mol. Physiol.) 20:L146-L154.

Breeze RG, Wheeldon EB (1977) The cells of the pulmonary airways. Am. Rev. Respir. Dis. 116:705- 717.

Brook RD, Rajagopalan S, Pope CA, Brook JR, Bhatnagar A et al. (2010) Particulate matter air pollution and cardiovascular disease. Circulation 121:2331-2378.

Brown C (2004) Emerging zoonoses and pathogens of public health significance: an overview. Rev. Sci. Tech. Off. Int. Epiz. 23:435-442.

Brown RE, Brain JD, Wang N (1997) The avian respiratory system: a unique model for studies of respiratory toxicosis and for monitoring air quality. Environ. Health Perspect. 105:188-200.

Brownlie R, Allan B (2011) Avian toll-like receptors. Cell Tissue Res. 343:121-130.

Brunekreef B, Dockery DW, Krzyzanowski M (1995) Epidemiologic studies on short-term effects of low levels of major ambient air pollution components. Environ. Health Perspect. 103:3-13.

BTS (2006) (British Thoracic Society) Burden of lung disease: a statistical report. http://ww.bts.com/libraries.

Buckner MMC, Finlay B (2011) Innate immunity cues virulence. Nature 472:179-180.

Burri PH (1985) Morphology and respiratory function of the alveolar unit. Int. Archs. Allergy Appl. Immun. 76:2-12.

Burroughs T., Knobler, S., Lederberg, J. (eds) (2002) The emergence of zoonotic diseases. National Academy Press, Washington DC.

Caiheir JF, Sawatzky DA, Kipari T, Houlberg K, Walbaum D et al. (2006) Resident pleural macrophages are key orchestrators of neutrophil recruitment in pleural inflammation. Am. J. Respir. Crit. Care Med. 173:540-547.

Callaghan M, Voynov JA (2006) Respiratory tract mucin genes and mucin glycoproteins in health and disease. Physiol. Rev. 86:245-278.

Camner P, Lundborg M, Låstbom L, Gerde P, Gross N, Jarstrand C (2002) Experimantal and calculated parameters on particle phagocytosis by alveolar macrophages. J. Appl. Physiol. 92:2608- 2616.

Canning BJ (2008) The cough reflex in animals: relevance to human cough research. Lung 186:S23- S28.

Carrasco L, Gómez-Villamandos JC, Bautista MJ, Hervás J, Pulido B, Sierra MA (1996) Pulmonary intravascular macrophages in deer. Vet. Res. 27:71-77.

Carrasco L, Sanchez C, Gomez-Villamandos JC (1999) The role of pulmonary intravascular macrophages in the pathogenesis of African horse sickness. J. Comp. Pathol. 121:2538.

Carter JD, Ghio AJ, Samet JM, Devlin RB (1997) Cytokine production by human airway epithelial cells after exposure to an air pollution particle is metal-dependent. Toxicol. Appl. Pharmacol. 46:180-188.

Chandler DB, Bayles G, Fuller WC (1988) Prostaglandin synthesis and release by subpopulations of rat macrophages. Am. Rev. Respir. Dis. 138:901-907. 
Chandler DB, Brannen AL (1990) Interstitial macrophage subpopulations: responsiveness to chemotactic stimuli. Tissue Cell 22:427-434.

Cheetham BF, Katz ME (1995) A role for bacteriophages in the evolution and transfer of bacterial virulence determinants. Mol. Microbiol. 18:201-208.

Chen H, Deng G, Li Z, Tian G, Li Y et al. (2004) The evolution of H5N1 influenza viruses in ducks in southern China. Proc. Natl. Acad. Sci., USA 101:10452-10457.

Chmiel JF, Davis PB (2003) State of art: why do the lungs of patients with cystic fibrosis become infected and why cant they clear the infection? Respir. Res. 4:8 (http://respiratory- research.com/content/4/1/8).

Chomel BB, Belotto A, Meslin FX (2007) Wildlife, exotic pets, and emerging zoonoses. Emerg. Infect. Dis. 13:6-11.

Cleaveland S, Laurenson MK, Taylor LH (2001) Diseases of humans and their domestic mammals: pathogen characteristics, host range and the risk of emergency. Phil. Trans. R. Soc. B, Lond. 356:991-999.

Conklin D (2011) Beware the air!: why particulate matter matters. Circ. Res. 108:644-647.

Conlon JM (2011) The contribution of skin antimicrobial peptides to the system of innate immunity in anurans. Cell Tissue Res. 343:201-212.

Crapo JD, Harmsen AG, Sherman MP, Musson RA (2000) Pulmonary immunobiology and inflammation in pulmonary diseases. Am. J. Respir. Crit. Care Med. 162:1983-1986.

Crowell RE, Heaphy E, Valdez YE, Mold C, Lehnert BE (1992) Alveolar and interstitial macrophage populations in the murine lung. Exp. Lung Res. 18:435-446.

Cuffs JHAJ, Meis JFGM, Hoogkamp-Korstanje JAA (1997) A primer on cytokines: sources, receptors, effects, and inducers. Clin. Microbiol. Rev. 10:742-780.

Currie RJW (1999) Ascites in poultry: recent investigations. Avian Path. 28:313-326.

Daszak P, Cunningham AA, Hyatt AD (2001) Anthropogenic environmental change and the emergence of infectious diseases in wildlife. Acta Trop. 78:103-116.

Decker WK, Xing D, Shepall EJ (2006) Dendritic cell immunotherapy for the treatment of neoplastic disease. Biol. Blood Marrow Transplantation 12:113-125.

Dehring DJ, Crocker SH, Wismar BL, Steinberg SM, Lowery BD, Cloutier CT (1983) Comparison of live bacteria infusions in a porcine model of acute respiratory failure. J. Surg. Res. 34:151-168.

Dehring DM, Wismar BL (1989) Intravascular macrophages in pulmonary capillaries of humans. Am. Rev. Respir. Dis. 139:1027-1029.

Dekich MA (1997) Broiler industry strategies for control of respiratory and enteric diseases. Poult. Sci. 77:1176-1180.

De Palma M, Lewis CE (2011) Macrophages limit chemotherapy. Nature 472:303-304.

Dethloff LA, Lehnert BE (1988) Pulmonary interstitial macrophages: isolation and flow cytometric comparisons with alveolar macrophages and blood monocytes. J. Leukocyte Biol. 43:80-90.

Devergne O (1996) A novel interleukin 12 p40-related protein induced by latent Epstein-Barr virus infection in B-lymphocytes. J. Virol. 157:1499-1507.

Dockery DW, Pope CA, Xu X, Spengler JD, Ware JH et al. (1993) An association between air pollution and mortality in six US cities. N. Engl. J. Med. 329:753-759.

Dougherty GJ, McBride WH (1984) Macrophage heterogeneity. J. Clin. Lab. Immun. 14:1-11. 
Dreher D, Cochand L, Kok M, Kiama SG, Gehr P et al. (2001) Genetic background of attenuated Salmonella typhimurium has profound influence on infection and cytokine patterns in human dendritic cells. J. Leukocyte Biol. 69:583-589.

DuPasquier L (ed) (1993) Evolution of the immune system, $3^{\text {rd }}$ edtn. Raven Press, New York.

Dzionek A, Fuchs A, Schmidt P, Cremer S, Sysk M et al. (2000) BDCA-2, BDCA-3, and BDCA-4: three markers for distinct subsets of dendritic cells in human peripheral blood. J. Immun. 165:6037- 6046.

Eckert DJ, Catcheside PG, Stadler DL, McDonald R, Hlavac MC, McEvoy RD (2006) Acute sustained hypoxia suppresses the cough reflex in healthy subjects. Am. J. Respir.Crit. Care Med. 173:506-511.

EPS (1996) Environmental Protection Agency: Air quality criteria for particulate matter. Res. Triangle Park, NC, US EPA (US EPA/600/P-95/00 1bF).

Fagerland JA, Arp LH (1990) A morphologic study of bronchus-associated lymphoid tissue in turkeys. Am. J. Anat. 189:4-34.

Fagerland JA, Arp LH (1993) Distribution and quantitation of plasma cells, T lymphocyte subsets, and B lymphocytes in bronchus-associated lymphoid tissue of chickens: age-related differences. Reg. Immun. 5:28-36.

Fan EO (2003) Economic impact and implications. Oxford University Press, Hong Kong.

Fathi M, Johansson A, Lundborg M, Orre L, Sköld MC, Canmer P (2001) Functional and morphological differences between human alveolar and interstitial macrophages. Exp. Mol. Pathol. 70:77-82.

Fawcett DW (1986) A text book of histology, 11 th edtn. WB Saunders, Philadelphia.

Fedde MR (1980) The structure and gas flow pattern in the avian lung. Poult. Sci. 59:26422653.

Fedde MR (1997) Relationship of structure and function of the avian respiratory system to disease susceptibility. Poult. Sci. 77:1130-1138.

Fedosenko G, Chernogoryk G, Roslyyyakova E, Kirillova N (2010) The improvement of the macrophages morphological characteristics in bronchial region in stable COPD patients under influence of tiotropium bromide. Eur. Respir. J. P4007 (www.erscongress2012.com/pages/default.aspx?id=1045...80607).

Fels AOS, Cohn ZA (1986) The alveolar macrophage. J. Appl. Physiol 60:353-371.

Ficken MD, Edwards JF, Lay JC (1986) Induction, collection, and partial characterization of induced respiratory macrophages of the turkey. Avian Dis. 30:766-771.

Field H, Young P, Yob JM, Mills J, Hall L, Mackenzie J (2001) The natural history of Hendra and Nipah viruses. Microbes and Infection 3:307-314.

Finley BB, Falkow S (1997) Common themes in microbial pathogenicity revisited. Microbiol. Mol. Biol. 61:136-169.

Finley BB, Buckner MMC (2011) Innate immunity cues virulence. Nature 472:179-180.

Fireman E, Onn A, Levo Y, Bugolovov E, Kivity S (1999) Suppressive activity of bronchial macrophages recovered by induced sputum. Allergy 54:111-118.

Fong L, Engelman EG (2000) Dendritic cells in cancer immunotherapy. Annu. Rev. Immun. 18:245-273.

Frankenberger M, Passlick B, Hofer T, Siebeck M, Maier KL, Ziegler-Heitbrock LHW (2000) Immunologic characterization of normal human pleural macrophages. Am. J. Respir. Cell Mol. Biol. 23:419-426. 
Franke-Ullmann G, Pförtner C, Walter P, Steinmüller C, Lohmann-Mathes ML, Kobzik L (1996) Characterization of murine lung interstitial macrophages in comparison with alveolar macrophages in vitro. J. Immun. 157:3097-3104.

Fries PN, Griebel PJ (2011) Mucosal dendritic cell diversity in the gastrointestinal tract. Cell Tissue Res. 343:33-41.

Fujii T, Hayashi S, Hogg JC, Mukae H, Suwa Y et al. (2002) Interaction of alveolar macrophages and airway epithelial cells following exposure to particulate matter produces mediators that stimulate the bone marrow. Am. J. Respir. Cell Mol. Biol. 27:34-41.

Fujii T, Hayashi S, Hogg JC, Vincent R, van Eeden SF (2001) Particulate matter induces cytokine expression in human bronchial epithelial cells. Am. J. Respir. Cell Mol. Biol. 25:265-271.

Gant VA, Hamblin AS (1985) Human bronchoalveolar macrophage heterogeneity demonstrated by histochemistry, surface markers, and phagocytosis. Clin. Exp. Immun. 60:539-545.

Garn H, Siese A, Stumpf S, Wensing A, Renz H, Gemsa D (2006) Phenotypical and functional characterization of alveolar macrophage subpopulations in the lungs of NO-exposed rats. Respir. Res. 7:4 (doi:10.1186/1465-9921-7-4).

Gehr P, Bachofen M, Weibel ER (1978) The normal human lung: ultrastructure and morphometric estimation of diffusion capacity. Respir. Physiol. 32:121-140.

Gehr P, Fabian B, Rothen-Rutishauser BM (2006) Fate of inhaled particles after interaction with the lung surface. Paediatr. Respir. Rev. 7S:S73-S75.

Gehr P, Schürch S, Berthiaume Y, Im H, Geiser M (1990b) Particle retention in airways by surfactant. J. Aerosol Sci. 3:27-43.

Gehr P, Schürch S, Geiser M, Hof VI (1990a) Retention and clearance mechanisms of inhaled particles. J. Aerosol. Sci. 21:S491-S496.

Geiser M (2002) Morphological aspects of particle uptake by lung phagocytes. Microsc. Res. Tech. 57:512-522.

Geiser P (2010) Update on macrophage clearance of inhaled micro- and nanoparticles. J. Aerosol Med. Pulm. Drug Deliv. 23:207-217.

Geiser M, Cruz-Orive LM, Hof VI, Gehr P (1990) Assessment of particle retention and clearance in the intrapulmonary conducting airways of hamster lungs with fractionator. J. Microsc. 160:75-88.

Geiser M, Im H, Gehr P, Cruz-Orive LM (1988) Histological and stereological analysis of particle deposition in the conducting airways of hamster lungs. J. Aerosol. Med. 1:19211.

Geiser M, Matter M, Maye I, Im Hof V, Gehr P, Schulz S (2003) Influence of air space geometry and surfactant on the retention of man-made vitreous fibers (MMVF 10a). Environ. Health Perspect. 111:895-901.

Geissmann F, Gordon S, Hume DA, Mowat AM, Randolph GJ (2010a) Unraveling mononuclear phagocyte heterogeneity. Nat. Rev. Immunol. 10:453-460.

Geissmann F, Manz MG, Jung S, Sieweke MH, Merad M, Ley K (2010b) Development of monocytes, macrophages, and dendritic cells. Science 327:656-661.

Gerlach B, Cordier SM, Schmukle AC, Emmerich CH, Rieser E, Hass TL (2011) Linear ubiquitination prevents inflammation and regulates immune signalling. Nature 471:591-596. 
Geurtsvankessel CH, Lambrecht BN (2008) Division of labour between dendritic cell subsets of the lung. Mucosal Immun. 1:442-450.

Gil J, Weibel ER (1971) Extracellular lining of bronchioles after perfusion-fixation of rat lungs for electron microscopy. Anat. Rec. 169:131-145.

Gill SS, Suri SS, Janardhan KS, Caldwell S, Duke T, Singh B (2008) Role of pulmonary intravascular macrophages in endotoxin-induced lung inflammation and mortality in a rat model. Respir. Res. 9:69 (doi: 10.1186/1465-9921-9-69).

Gjomarkaj M, Pace E, Melis M, Spatafora M, Profita M et al. (1999) Phenotypic and functional characterization of normal rat pleural macrophages in comparison with autologous peritoneal and alveolar macrophages. Am. J. Respir. Cell Mol. Biol. 20:135-142.

Godfrey RW (1997) Human airway epithelial tight junctions. Microsc. Res. Tech. 38:488-499.

Goldstein E, Bartlema HC (1977) Role of the alveolar macrophage in pulmonary bacterial defense. Bull. Eur. Physiol. Pathol. Respir. 13:57-67.

Gonzalez-Juarrero M, Orme IM (2001). Characterization of murine lung dendritic cells infected with Mycobacterium tuberculosis. Infection Immunity 69:1127-1133.

Gordon S (2002) Pattern recognition receptors: doubling up for the innate immune response. Cell 111:927-930.

Gordon S,Taylor PR (2005) Monocyte and macrophage heterogeneity. Nat. Rev. Immunol. 5:953-864.

Grant MM, Brain JD, Vinegar A (1981) Pulmonary defense mechanisms in boa constrictor. J. Appl. Physiol. 50:979-983.

Green GM (1973) Alveolar-bronchiolar transport mechanisms. Arch. Intern. Med. 131:109114.

Green GM (1984) Similarities of host defense mechanisms against pulmonary infectious diseases in animals and man. J. Toxicol. Environ. Health 13:471-478.

Green GM, Jakab GJ, Low RB, Davis GS (1977) Defense mechanisms of the respiratory membrane. Am. Rev. Respir. Dis. 115:479-514.

Green GM, Kass EH (1964) The role of the alveolar macrophage in the clearance of bacteria from the lung. J. Exp. Med. 119:167-182.

Greger M (2007) The human/animal interface: emergence and resurgence of zoonotic infectious diseases. Crit. Rev. Microbiol. 33:243-299.

Hammerstrom J (1980) Structure and function of human effusion macrophages from patients with malignant and benign disease. Acta Pathol. Microbiol., Scand. 88:191200.

Harada H, Imamura M, Okunishi K, Nakagome K, Matsumoto T et al. (2009) Upregulation of lung dendritic cell functions in elastase-induced emphysema. Int. Arch. Allergy Immun. 149:25-30.

Harkema JR, Mariassy A, George J, Hyde DM, Plopper C (1991) Epithelial cells of the conducting airways: a species comparison. In: Lung biology in health and disease: the airway epithelium (Farmer SG, Hay DWP, eds). Marcel Dekker Inc., New York, pp. 339.

Hart DN (1997) Dendritic cells: unique leukocyte populations which control the primary immune response. Blood 90:3245-3287. 
Hartwig, Davies WA, Stossel TP (1977) Evidence for contractile protein translocation in macrophage spreading, phagocytosis and phagolysosome formation. J. Cell Biol. 75:956-967.

Havenith CEG, van Miert PPMC, Breedjik AJ, Beelen RHJ, Hoefsmit ECM (1993) Migration of dendritic cells into the draining lymph nodes of the lung after intratracheal instillation. Am. J. Respir. Cell Mol. Biol. 9:484-488.

Hawley RJ, Beaman BK, Williams MC, Yeager H (1979) The ultrastructure of bronchial macrophages and lymphocytes in sarcoidosis. Human Pathol. 10:155-163.

Hazlett L, Wu M (2011) Defensins in innate immunity. Cell Tissue Res. 343:175-188.

Hess CM, Edwards SV (2002) The evolution of the major histocompartibility complex in birds. Bioscience 52:423-431.

Hirano S (1996) Interaction of rat alveolar macrophages with pulmonary epithelial cells following exposure to lipopolysaccharide. Arch. Toxicol. 70:3-4.

Hof IM, Klauser M, Gehr P (1990) Phagocytic properties and organelle motility of pulmonary macrophages from smokers and nonsmokers estimated in vitro by magnetometric means. Eur. Respir. J. 3:157-162.

Hoffman JA, Hetru C (1992) Insect defensins: inducible antibacterial peptides. Immun. Today 13:411- 415.

Holt PG (1979) Alveolar macrophage. I. A simple technique for the preparation of high numbers of viable alveolar macrophages from small laboratory animals. J. Immun. Methods 27:189-198.

Holt PG (2005) Pulmonary dendritic cells in local immunity to inert and pathogenic antigens in the respiratory tract. Pro. Am. Thorac. Soc. 2:116-120.

Holt PC, Degebrodt A, Venaille T, O'Leary C, Krska K et al. (1985) Preparation of interstitial lung cells by enzymatic digestion of tissue slice: preliminary characterization by morphology and performance in functional assays. Immunology 54:139-147.

Holt PC, Marner LA, Papadimitriou JM (1982) Alveolar macrophages: functional heterogeneity within macrophage populations from rat lung. Austr. J. Exp. Biol. Sci. 60:607-618.

Holt PG, Haining S, Nelson DJ, Sedgwick JD (1994) Origin and steady-state turnover of class II MHC- bearing dendritic cells in the epithelium of the conducting airways. J. Immun. 153:256-261.

Holt PG, Schon-Hegrad MA, Oliver J (1988) MHC class II antigen-bearing dendritic cells in pulmonary tissues of the rat (regulation of antigen presentation activity by endogenous macrophage populations). J. Exp. Med. 167:262-274.

Holt PG, Strickland DH, Wikstrom ME, Jahnsen FL 2008) Regulation of immunological homeostasis in respiratory tract. Nat. Rev. Immun. 8:142-152.

Hughes AL (1999) Adaptive evolution of genes and genomes. Oxford University Press, New York.

Hughes AL, Neil M (1989) Evolution of the major histocompatibility complex: independent origin of nonclassical class I genes in different groups of mammals. Mol. Biol. Evol. 6:559-579.

IPCC (2007) Intergovernmental Panel on Climate Change: UNEP/WMO) In: Fourth assessment report: climate change (Pachauri RK, Reisinger A eds). Switzerland, Geneva, pp. 104. 
Ishii H, Hayashi S, Hogg JC, Fujii T, Goto Y et al. (2005) Alveolar macrophage-epithelial cell interaction following exposure to atmospheric particles induces the release of mediators involved in monocyte mobilization and recruitment. Respir. Res. 6:87 (doi:10.1186/1465-9921- 6-87).

Jahnsen FL, Strickland DH, Thomas JA, Tobagu IT, Napoli S, Zosky GR (2006) Accelerated antigen sampling and transport by airway mucosal dendritic cells following inhalation of bacterial stimulus. J. Immun. 177:5861-5867.

Janeway CA (1993) How the immune system recognizes invaders. Sci. Amer. 269:72-79.

Johansson A, Lundborg M, Sköld CM, Lundhl J, Tornling G et al. (1997) Functional, morphological, and phenotypical differences between rat alveolar and interstitial macrophages. Am. J. Respir. Cell Biol. 16:582-588.

Johnson JE, Philp JR (1977) The defense of the lung: studies of the role of cell-mediated immunity. Johns Hopkins Med. J. 141:126-134.

Kaczmarek M, Frydrychowicz M, Nowicka A, Kozlowska M, Batura-Gabryel H et al. (2008) Influence of pleural and apoptosis regulating proteins of malignant cells. J. Physiol. Pharmacol. 59:321-330.

Kampfrath T, Maiseyeu A, Ying Z, Shah Z, Deiuliis JA et al. (2011) Chronic fine particulate matter exposure induces systemic vascular dysfunction via NADPH oxidase and TLR4 pathways. Circ. Res. 108:716-726.

Kapur V, Chauhan S, D'Cruz, Sachdev (2009) Kartagener's syndrome. Lancet 373:1973 (doi:10.1016/S0140-6736(09)60306).

Kaufman JD (2010) Does air pollution accelerate progression of atherosclerosis? J. Am. Coll. Cardiol. 56:1809-1811.

Kelly J (1990) Cytokines of the lung. Am. Rev. Respir. Dis. 141:765-788.

Kiama SK, Adekunle JS, Maina JN (2008) Comparative in vitro study of interactions between particles and respiratory surface macrophages, erythrocytes and epithelial cells of the chicken and the

rat. J. Anat. 213:452-463.

Kiama SG, Cochand L, Karlsson LM, Nicod LP, Gehr P (2001) Evaluation of phagocytic activity in human monocyte-derived dendritic cells. J. Aerosol Med. 14:289-299.

Kiama SG, Dreher D, Cochand L, Kok M, Obregon C et al. ehr P (2006) Host cell responces of Salmonella typhimurium infected human dendritic cells. Immun. Cell Biol. 84:475481.

Kilburn H (1968) A hypothesis for pulmonary clearance and its implications. Am. Rev. Respir. Dis. 98:449-463.

Klein J (1986) Natural history of the major histocompatibility complex. Wiley, New York.

Klika E, Scheuermann DW, de Groodt-Lasseel MHA, Bazantova I, Switka A. (1996) Pulmonary macrophages in birds (barn owl, Tyto tyto alba), domestic fowl (Gallus domestica), quail (Coturnix coturnix), and pigeons (Columba livia). Anat. Rec. 256:8797.

Klinke DJ (2006) An age related model of dendritic trafficking in the lung. Am. J. Physiol. 291:L1038- L1049.

Kobzik L, Godleski JJ, Barry BE, Brain JD (1988) Isolation and antigenic identification of hamster lung interstitial macrophages. Am. Rev. Resp. Dis. 138:908-914.

Kobzik L, Hancock WW, O'Hara C, Todd R, Godleski JJ (1986) Antigenic profile of human lung interstitial and alveolar macrophages. Lab. Invest. 54:32A. 
Krauss H, Weber A, Appel M, Enders B, Isenberg D et al. (2003) Zoonoses: infectious diseases transmissible from animals to humans, 3rd edtn. ASM Press, American Society for Microbiology, Washington DC.

Krombach F, Münzing S, Allmeling AM, Gerlach JT, Behr J, Dörger M (1977) Cell size of alveolar macrophages: an interspecies comparison. Envriron. Health Perspect. 105:1261-1263.

Lambrecht BN, Prins JB, Hoogsteden HC (2001) Lung dendritic cells and host immunity to infection. Eur. Respir. J. 18:692-704.

Lambrecht BN, Salomon B, Klatzmann D, Pauwels RA (1998) Dendritic cells are required for the development of chronic eosinophilic airway inflammation in response to inhaled antigen in sensitized mice. J. Immun. 160:4090-4097.

Laskin DL, Weinberger B, Laskin JD (2001) Functional heterogeneity in liver and lung macrophages. J. Leukocyte Biol. 70:163-170.

Laurenzi GA, Berman L, First M, Kass EH (1964) A quantitative study of the deposition and clearance of bacteria in the murine lung. J. Clin. Invest. 43:759-768.

Lavnikova N, Prokhorova S, Helyar L, Laskin DL (1993) Isolation and partial characterization of subpopulations of alveolar macrophages, granulocytes, and highly enriched interstitial macrophages from rat lung. Am. J. Respir Cell Mol. Biol. 8:384-392.

Lee CA (1996) Pathogenicity islands and the evolution of bacterial pathogens. Infect. Agents Dis. 5:1-7.

Lee JW, McKibbin W (2003) Globalization and disease: the case of SARS: working paper No. 2003/16. The Brookings Institution, Research School of Pacific and Asian Studies, Australian National University (Canberra) and Washington DC.

Lehnert BE (1992) Pulmonary and thoracic macrophage subpopulations and clearance of particles from the lung. Environ. Health Perspect. 97:17-46.

Lehnert BE, Ortiz JB, London JE, Valdez YE, Cline AF et al. (1990) Migratory behaviours of alveolar macrophages during the alveolar clearance of light to heavy burdens of particles. Exp. Lung Res. 16:451-479.

Lehnert BE, Valdez Y, Holland L (1985) Pulmonary macrophages: alveolar and interstitial populations. Exp. Lung Res. 9:177-197.

Li N, Wang M, Oberley TD, Sempf JM, Nel AE (2002) Comparison of the pro-oxidative and proinflammatory effects of organic diesel exhaust particle chemicals in bronchial epithelial cells and macrophages. J. Immun. 169:4531-4541.

Lippmann M, Schlesinger RB (1984) Interspecies comparison of particle deposition and mucociliary clearance in tracheobronchial airways. J. Toxicol. Environ. Health 13:441469.

Lipscomb MF, Masten BJ (2002) Dendritic cells: immune regulators in health and disease. Physiol Rev 82:97-130.

Litman GW (1996) Sharks and the origins of vertebrate immunity. Sci. Amer.1996:67-71.

Litman GW, Rast JP, Shamblott MJ, Haire RN, Hurst M et al. (1993) Phylogenetic diversification of immunoglobulin genes and the antibody repertoire. Mol. Biol. Evol. 10:60-72.

Liu YJ (2005) IPC: professional type 1 interferon-producing cells and plasmacytoid dendritic cell precursors. Annu. Rev. Immun. 23:275-306. 
Lohmann-Matthes ML, Steinmüller C, Franke-Ullmann G (1994) Pulmonary macrophages. In: Pulmonary immune cells (Costael U, Kroegel C eds). Eur. Resp. J. 7:1678-1689.

Lommatzsch M, Bratke K, Bier A, Julius P, Kuepper M et al. (2007) Airway dendritic cell phenotypes in inflammatory diseases of the human lung. Eur. Respir. J. 30:878-886.

Lommatzsch M, Bratke K, Knappe T, Bier A, Dreschler K et al. (2010) Acute effects of tobacco smoke on human airway dendritic cells in vivo. Eur. Respir. J. 35:1130-1136.

Longworth KE, Jarvis KA, Tyler WS, Steffey EP, Staub NC (1994) Pulmonary intravascular macrophages in horses and ponies. Am. J. Vet. Res. 55:382-388.

Lorz C, López J (1997) Incidence of air pollution in the pulmonary surfactant system of the pigeon (Columba livia). Anat. Rec. 249:206-212.

Lundborg M, Johansson A, Låstbom L, Camner P (1999) Ingested aggregates of ultrafine carbon particles and interferon- $\gamma$ impair rat alveolar macrophage function. Environ. Res. 81:309-315.

Lundborg M, Johard U, Låstbom L, Gerde P, Camner P (2001) Human alveolar macrophage function is impaired by aggregates of ultrafine carbon particles. Environ. Res. 86:244-253.

Mahsud I-U, Din S-U (2006) Kartagener's syndrome: case report. Gomal J. Med. Sci. 4:79-81.

Maina JN (1989) The morphology of the lung of the East African tree frog Chiromantis petersi with observations on the skin and the buccal cavity as secondary gas exchange organs: A TEM and SEM study. J. Anat. 165:29-43.

Maina JN (2005) The lung air-sac system of birds: development, structure, and function. SpringerVerlag, Berlin.

Maina JN, Cowley HM (1998) Ultrastructural characterization of the pulmonary cellular defences in the lung of a bird, the rock dove, Columba livia. Proc R. Soc. B, Lond 265:1567-1572.

Maina JN, King AS (1982) The thickness of the avian blood-gas barrier: qualitative and quantitative observations. J. Anat. 134:553-562.

Maina JN, King AS, Settle G (1989) An allometric study of the pulmonary morphometric parameters in birds, with mammalian comparison. Phil. Trans. R. Soc. B, Lond 326: $1-57$.

Maina JN, Maloiy GMO (1988) A scanning and transmission electron microscopic study of the lung of a caecilian Boulengerula taitanus. J. Zool., Lond 215:739-751.

Maina JN, West JB (2005) Thin and strong! The bioengineering dilemma in the structural and functional design of the blood-gas barrier. Physiol. Rev. 85:811-844.

Maldonado CA, Sundblad V, Salatino M, Elia J, Garcia LN et al. (2011) Cell-type specific regulation of galectin-3 expression by glucocorticoids in lung Clara cells and macrophages. Histol. Histopath. 6:747-759.

Mateen FJ, Brook RD (2011) Air pollution as an emerging global risk factor for stroke. JAMA 305:1240- 1241.

McClung, CR (2011) Defence at dawn. Nature 470:44-45.

McKenna K, Beignon A, Bhardwaj N (2005). Plasmacytoid dendritic cells: linking innate and adaptive immunity. J. Virol. 79:17-27.

Mckibbin WJ, Sidorenko AA (2006) Globalization macroeconomic consequences of pandemic influenza. Lowy Institute for International Policy, Sydney (Australia). 
McShane D, Davies JC, Wodehouse T, Bush A, Geddes D, Alton EWFW (2004) Normal nasal mucociliary clearance in CF children: evidence against a CFTR-related defect. Eur. Respir. J. 24:95-100.

Meban C (1980) Thicknesses of the air-blood barriers in vertebrate lungs. J. Anat. 131:299307.

Mensah GA, Brain JD (1982) Deposition and clearance of inhaled aerosol in the respiratory tract of chickens. J. Appl. Physiol. 53:1423-1428.

Meuret G, Schildknecht O, Joder P, Senn H (1980) Proliferation activity and bacteriostatic potential of human blood monocytes, macrophages in pleural effusions, ascites, and of alveolar macrophages. Blut 40:17-25.

Meyer D, Mack SJ (2003) Major histocompatibility complex (MHC) genes: polymorphism. In: Nature Encyclopedia of Human Genome. Macmillan Publishers Ltd, Nature Publishing Group, London. group/www.ehgoline.net.

Meyer D, Thompson G (2001) How selection shapes variation of the human major histocompatibility complex: a review. Ann. Hum. Genet. 65:1-26.

Mills JN, Gage KL, Khan AS (2010) Potential influence of climate change on vector-borne and zoonotic diseases: a review and proposed research plan. Environ. Health Perspect. 118:1507-1514.

Molina RM, Brain JD (2007) In vivo comparison of cat alveolar and pulmonary intravascular macrophages: phagocytosis, particle clearance, and cytoplasmic motility. Exp. Lung Res. 33:53-70.

Moniuszko M, Bodzenta-Łukaszyk A, Kowal K (2007) Bronchial macrophages in asthmatics reveal decreased CD16 expression and substantial levels of receptors for IL-10 but not IL-4 and IL-7. Folia Histochem. 45:181-189.

Morrissette N, Gold E, Aderem A (1999) The macrophage - a cell for all seasons. Trends Cell Biol. 9:199-201.

Morrow PE (1988) Possible mechanisms to explain dust overloading of the lungs. Fundam. Appl. Toxicol. 10:369-384.

Mouton D, Bouthillier Y, Biozzi G, Stiffel C (1963) Phagocytosis of Salmonellae by reticuloendothelial cells of new-born piglets lacking natural antibody. Nature 197:706-712.

Mulnix AB, Dunn PE (1995) Molecular biology of the immune response. In: Molecular model systems in the Lepidoptera (Goldsmith MR, Wilkins AS, eds). Cambridge University Press, New York, pp. 369-395.

Myers RK, Arp LH (1987) Pulmonary clearance and lesions of lung and air sac in passively immunized and unimmunized turkeys following exposure to aerosolized Escherichia coli. Avian Dis. 31:622-628.

Nagashima A, Yasumoto K, Nakahashi H, Takeo S, Yano T, Nomoto K (1987) Antitumour activity of pleural cavity macrophages and its regulation by pleural cavity lymphocytes in patients with lung cancer. Cancer Res. 47:5497-5500.

Nagdeve DA (2004) Environmental pollution and control: a case study of Delhi Mega City. Population Environ. 25:461-473.

Nemmar A, Vanquickenborne B, Dinsdale D, Thomeer M, Hoylaerts MF et al. (2002) Passage of inhaled particles into the blood circulation in humans. Circulation 105:411-414. 
Nganpiep L, Maina JN (2002) Composite cellular defense stratagem in the avian respiratory system: functional morphology of the free (surface) macrophages and specialized pulmonary epithelia. J. Anat. 200:499-516.

Nguyen BT, Peterson PK, Verbrugh HA, Quie PG, Hoidal JR (1982) Difference in phagocytosis and killing by alveolar macrophages from humans, rabbits, rats, and hamsters. Infect. Immun. 36:504-509.

Nicod LP (1997) Function of human lung dendritic cells. In: Lung health and disease (Lipscomb MF, Russels SW, eds). Marcel Dekker Inc., New York, pp. 311-334.

Nicod LP (2005) Lung defences: an overview. Europ. Respir. Rev. 95:45-50.

Niehaus GD, Schumacker PR, Saba TM (1980) Reticuloendothelial clearance of blood-borne particulates. Ann. Surg. 191:479-489.

Ochs DL, Toth TE, Pyle RH, Siegel PB (1988) Cellular defense of the avian lung respiratory system: effects of Pasteurella multocida on respiratory burst activity of avian respiratory tract phagocytes. Am. J. Vet. Res. 49:2081-2084.

Ooi H, Arakawa M, Ozawa H (1994) A morphological study of acute respiratory tract lesions in a lipopolysaccharide instilled rat model. Arch. Histol. Cytol. 57:87-105.

Pabst R, Tschernig T (2002) Perivascular capillaries in the lung: an important but neglected vascular bed in immune reactions? J. Allergy Clin. Immun. 110:209-214.

Parbhakar OP, Duke T, Twonsend HGG, Singh B (2005) Depletion of pulmonary intravascular macrophages partially inhibits lipopolysaccharide-induced lung inflammation in horses. Vet. Res. 36:557-569.

Patz JA, Daszak P, Tabor GM, Aguirre AA, Pearl M et al. (2004) Unhealthy landscapes: policy recommendations on land use change and infectious disease emergence. Environ. Health Perspect. 112:1092-1098.

Patz JA, Wolfe ND (2002) Global ecological change and human health. In: Conservation medicine: ecological health and practice (Aguirre AA, Osfeld RS, Tabor GM, House C, Pearl MC, eds). Oxford University Press, New York, pp. 167-181.

Peão MND, Águas AP, Grande NR (1993) Morphological evidence for migration of particleladen macrophages through the interalveolar pores of Kohn in the murine lung. Acta Anat. 147:227- 232.

Pennial R, Spitznagel JK (1975) Chicken neutrophils: oxidative metabolism in phagocytic cells devoid of myeloperoxidase. Proc. Natl. Acad Sci., USA 72:5012-5015.

Peters A, Wichmann HE, Tuch T, Heinrich J, Heyder J (1997) Respiratory effects are associated with the number of ultrafine particles. Am. J. Respir. Crit. Care Med. 155:1376-1383.

Pope CA (2000) Epidemiology of fine particle air pollution and human health: biologic mechanisms and who's at risk? Environ. Health Perspect. 108:713-723.

Pope CA, Burnett RT, Thun MJ, Calle EE, Krewski D, Ito K, Thurston GD (2002) Lung cancer, cardiopulmonary mortality, and long-term exposure to fine particulate air pollution. J. Am. Med. Assoc. 287:1132-1141.

Poth CM, Matfin G (2010) Essentials of pathophysiology. Lippincott Williams, New York.

Power CK, Burke CM, Sreenan S, Hurson B, Poulter LW (1994) T-cell and macrophage subsets in the bronchial wall of clinically healthy subjects. Eur. Respir. J. 7:437-441.

Prokhorova S, Lavnikova N, Laskin DL (1994) Functional characterization of interstitial macrophages and subpopulations of alveolar macrophages from rat lung. $J$. Leukocyte Biol. 55:141-146. 
Rawlins EL (2011) The building blocks of mammalian lung development. Dev. Dyn. 240:463476.

Reaven EP, Axline SG (1973) Subplasmalemmal microfilaments and microtubules in resting and phagocytosing cultivated macrophages. J. Cell Biol. 59:12-27.

Reese S, Dalamani G, Kaspers B (2006) The avian lung-associated immune system: a review. Vet. Res. 37:311-324.

Reid CD (1997) The dendritic cell lineage in hemopoiesis. Br. J. Hematol. 96:217-223.

Rehman, D. A. 1998. Detection and identification of previously unrecognized microbial pathogens. Emerg. Infect. Dis. 4:382-389.

Rohmann K, Tschernig T, Pabst R, Goldmann T, Drömann D (2011) Innate immunity in the human lung: pathogen recognition and lung disease. Cell Tissue Res. 343:167-174.

Rubovitch V, Gershnabel S, Kalina M (2007) Lung epithelial cells modulate the inflammatory response of alveolar macrophages. Inflammation 30:236-243.

Rybicka K, Daly BDT, Migliore JJ, Norman JC (1974) Intravascular macrophages in normal calf lung. an electron microscopic study. Am. J. Anat. 139:353-368.

Sachan N, Singh VP (2010) Effects of climatic changes on the prevalence of zoonotic diseases. Vet. World 3:519-522.

Saetta M, Di Stefano A, Maestrelli P, Ferraresso A, Drigo R et al. (1993) Activated Tlymphocytes and macrophages in bronchial mucosa of subjects with chronic bronchitis. Am. Rev. Respir. Dis. 147:301-306.

Sahn SA, Potts DE (1978) The effect of tetracycline on rabbit pleura. Am. Rev. Respir. Dis. 117:493- 499.

Said IS, Foda HD (1989) Pharmacological modulation of lung injury. Amer. Rev. Respir. Dis. 139:1553- 1564.

Sallusto F, Lanzavecchia A (2002) The instructive role of dendritic cells on T-cell responses. Arthritis Res. 4 Suppl. 3:S127-S132.

Sanders CJ, Doherty PC, Thomas PG (2011) Respiratory epithelial cells in innate immunity to influenza virus infection. Cell Tissue Res. 343:13-21.

Satthaporn S, Eremin O (2001) Dendritic cells (I): biological functions. J. R. Coll. Surg. Edinb. 46:9-20.

Sbiera S, Wortmann S, Fassnacht M (2008) Dendritic cell based immunotherapy - a promising therapeutic approach for endocrine malignancies. Hormone Metab. Res. 40:89-98.

Schaumann F, Borm PJ, Herbrich A, Knoch J, Pitz M et al. (2004) Metal-rich ambient particles $\left(\mathrm{PM}_{2.5}\right)$ cause airway inflammation in healthy subjects. Am. J. Crit. Care Med. 170:898-903.

SchnebergerD, Raz-Aharonson K, Singh B (2011) Monocyte and macrophage heterogeneity and Toll- like receptors in the lung. Cell Tissue Res. 343:97-106.

Schon-Hegrad MA, Oliver J, McMenamin PG, Holt PG (1991) Studies on the density, distribution and surface phenotype of intraepithelial class II major histocompatibility complex antigen (Ia)- bearing dendritic cells (DC) in the conducting airways. J. Exp. Med. 173:1345-1356.

Schott M, Seissler J (2003) Dendritic cell vaccination: new hope for the treatment of metastasized endocrine malignancies. Trends Endocrinol. Metab. 14:156-162.

Schulz H, Harder N, Ibald-Mulli A, Khandoga A, Koenig W et al. (2005) Cardiovascular effects of fine and ultrafine particles. J. Aerosol. Med. 18:1-22. 
Schürch S, Gehr P, Hof Im, Geiser M, Green F (1990) Surfactant displaces particles toward the epithelium in airways and alveoli. Respir. Physiol. 80:17-32.

Schwartz J (1994) Why are people dying of high air pollution? Environ. Res. 64:26-35.

Sebring RJ, Lehnert BE (1992) Morphometric comparisons of rat alveolar macrophages, pulmonary interstitial macrophages, and blood monocytes. Exp. Lung. Res. 18:479496.

Sestini P, Tagliabue A, Boraschi D (1984) Modulation of macrophage suppressive activity and prostaglandin release by lymphokines and interferon: comparison of alveolar, pleural and peritoneal macrophages. Clin. Exp. Immun. 58:573-580.

Sharma S, Yang SC, Batra RK, Dubinett SM (2003) Intratumoral therapy with cytokine genemodified dendritic cells in murine lung cancer models. Methods Mol. Med. 5:711722.

Shellito J, Esparza C, Armstrong C (1987) Maintenance of the normal rat alveolar macrophage population: the roles of monocyte influx and alveolar macrophage proliferation in situ. Am. Rev. Respir. Dis. 135:78-82.

Shimotakahara A, Kuebler JF, Vieten G, Metzelder MI, Petersen C, Ure BM (2007) Pleural macrophages are the dominant cell population in the thoracic cavity with an inflammatory cytokine profile similar to peritoneal macrophages. Pediatr. Surg. Int. 23:447-451.

Sibile Y, Reynolds HY (1990) Macrophages and polymorphonuclear neutrophils in lung defense and injury. Am. Rev. Respir. Dis. 141:471-501.

Sica A, Bronte V (2007) Altered macrophage differentiation and immune dysfunction in tumour development. J. Clin. Invest. 117:1155-1166.

Sichletidis L, Tsiotsios I, Gavriilidis A, Chloros D, Gioulekas D et al. (2005) The effects of environmental pollution on the respiratory system of children in Western Macedonia, Greece. J. Invest. Allergol. Clin. Immun. 15:117-123.

Singh B, Pearce JW, Gamage LNA, Janardhan K, Cadwell S (2004) Depletion of pulmonary intravascular macrophages inhibits acute lung inflammation. Am. J. Physiol. 286:L363-L372.

Sorokin SP, Brain JD (1975) Pathways of clearance in mouse lungs exposed to iron oxide aerosols. Anat. Rec. 181:581-626.

Sorokin SP, Hoyt RF, Grant MM (1984) Development of macrophage in the lungs of fetal rabbits, rats, and hamsters. Anat. Rec. 208:103-121.

Spira A (1996) Disorders of the respiratory system. In: Diseases of cage and aviary birds (Rosskopf W, Woerpel R, eds). Lea and Febiger, Baltimore, pp. 415-428.

Spiteri MA, Clarke SW, Poulter LW (1992) Isolation of phenotypically and functionally distinct macrophage subpopulations from human bronchoalveolar lavage. Eur. Resp. J. 5:717-726.

Spritzer AA, Watson JA, Auld JA, Guetthoff MA (1968) Pulmonary macrophage clearance. The hourly rates of transfer of pulmonary macrophages to the oropharynx in the rat. Arch. Environ. Health 17:726-730.

Spurgin LG, Richardson DS (2010) How pathogens drive genetic diversity: MHC, mechanisms and misunderstandings. Proc. R. Soc. B, Lond. 277:979-988.

Stearns RC, Barnas GM, Walski M, Brain JD (1986) Phagocytosis in the gas exchange region of avian lungs. Fed. Proc. 45:959. 
Steinman RM (1991) The dendritic cell system and its role in immunogenicity. Annu. Rev. Immun. 9:271-296.

Steinman RM, Cohn ZA (1973) Identification of a novel cell type in peripheral lymphoid organs of mice: I. Morphology, quantitation, tissue distribution. J. Exp. Med. 137:1142-1162.

Steinmüller C, Franke-Ullmann G, Lohman-Matthes ML, Emmendörffer A (2000) Local activation of non- specific defense against a respiratory model infection by application of interferon- $\gamma$ : comparison between rat alveolar- and interstitial lung macrophages. Am. J. Respir. Cell Mol. Biol. 22:481- 490.

Stossel TP (1978) Contractile proteins in cell structure and function. Ann. Rev. Med. 29:427457.

Stossel TP, Hartwig JH (1976) Interactions of actin, myosin and new actin-binding protein of rabbit pulmonary macrophages. II. Role of cytoplasmic movement and phagocytosis. J. Cell Biol. 68:602-619.

Strange C, Tomlinson JR, Wilson C, Harley R, Miller KS, Sahn SA (1989) The histology of experimental pleural injury with tetracycline, empyema, and carrageenan. Exp. Mol. Pathol. 51:205-219.

Suwa T, Hogg JC, Quinlan KB, Ohgami A, Vincent R, van Eeden SF (2002) Particulate air pollution induces progression of atherosclerosis. J. Am. Coll. Cardiol. 39:935-942.

Syme R, Gluck S (2001) Generation of dendritic cells: role of cytokines and potential clinical applications. Trans. Apheres Sci. 24:117-124.

Takizawa H, Beckmann JD, Shoji S, Claassen LR, Ertl RF et al. (1990) Pulmonary macrophages can stimulate cell growth of bovine bronchial epithelial cells. Am. J. Respir. Cell Mol. Biol. 2:233- 244.

Thet LA, Wrobel DJ, Crapo JD (1983) Morphologic aspects of the protection by endotoxin against acute and chronic oxygen-induced lung injury in adult rats. Lab. Invest. 48:448-457.

Tilman D, Fargione J, Wolff B, D'Antonio C, Dobson A et al. (2001) Forecasting agriculturally driven global environmental change. Science 292:281-284.

Toth TE, Siegel PB (1986) Cellular defence for the avian respiratory tract: paucity of freeresiding macrophages in the normal chicken. Avian Dis. 30:67-75.

Toth TE, Siegel PB, Veit H (1987) Cellular defense of the avian respiratory system - influx of phagocytes: elicition versus activation. Avian Dis. 31:67-75.

Toth TE, Pyle RH, Caceci T, Siegel PB, Ochs D (1988) Cellular defense of the avian respiratory system: influx and nonopsonic phagocytosis by respiratory phagocytes activated by Pasteurella multocida. Infect. Immun. 56:1171-1179.

Tschernig T, Pabst R (2009) What is the clinical relevance of different lung compartments? BMC Pulm. Med. 9:39 (doi:10.1186/1471-2466-9-39).

Tschernig T, de Vries VC, Debertin AS, Braun A, Wallers T et al. (2006) Density of dendritic cells in the human tracheal mucosa is age dependent and site specific. Thorax 61:986-991.

Tsukioka T, Takemura S, Minamiyama Y, Nishiyama N, Mizuguchi S et al. (2007) Local and systemic impacts of pleural oxygen exposure in thoracotomy. BioFactors 30:117-128.

Tucker A, McMurtry IF, Reeves JT, Alexander AF, Will DH, Grover RF (1975) Lung vascular smooth muscle as a determinant of pulmonary hypertension at high altitude. Am. J. Physiol. 228:762- 778 . 
UNEP-WHO (1994) U.N. Environment Program and WHO Report: air pollution in the world's megacities. Environment 36:5-37.

Vanbervliet B, Bendriss-Vermare N, Massacrier C, Homey B, Boutillier O et al. (2003) The inducible CXCR3 ligands control plasmacytoid dendritic cell responsiveness to the constitutive chemokine stromal cell-derived factor-1 (SDF-1)/CXCL12. J. Exp. Med. 198:823-830.

van den Hooven EH, de Kluizenaar Y, Pierik FH, Hofman A, van Ratingen SW et al. (2011) Air pollution, blood pressure, and the risk of hypertensive complications during pregnancy: The generation R study. Hypertension 57:406-412.

van Furth R (1970) The origin and turnover of promonocytes, monocytes and macrophages in normal mice. In: Mononuclear phagocytes (van Furth R, ed). Blackwell, Oxford, pp. 151-165.

van Furth R (1982) Current view on the mononuclear phagocyte system. Immunobiology 161:178-185.

van Haarst JMV, Hoogsteden HC, de Wit HJ, Verhoeven, GT, Havenith CEG, Drexhage HA (1994) Dendritic cells and their precursors isolated from human bronchoalveolar lavage: immunocytologic and functional properties. Am. J. Respir. Cell Mol. Biol. 11:344-350.

Vassallo R, Walters PR, Lamont J, Kottom TJ, Yi ES, Limper AH (2010) Cigarette smoke promotes dendritic cell accumulation in COPD; a lung tissue research consortium study. Respir. Res. 11:45 (http://respiratory-research.com/content/11/1/45).

von Garnier C, Nicod LP (2009) Immunology taught by lung dendritic cells. Swiss Med. Wkly Online Publ. $8^{\text {th }}$ Jan, 2009, pp. 9.

von Garnier C, Filgueira L, Wikstrom M, Smith M, Thomas JA, Strickland DH (2005) Anatomical location determines the distribution and function of dendritic cells and other APCs in the respiratory tract. J. Immun. 175:1609-1618.

Walter E, Dreher D, Kok M, Thiele L, Kiama SG et al. (2001) Hydrophilic poly (DL-lactideco-glycolide) microspheres for the delivery of DNA to human-derived macrophages and dendritic cells. J. Controlled Release 76:149-168.

Wang, W., Barnaby, J.Y., Tada, Y., Li, H., Tör, H. et al. (2011) Timing of plant immune responses by a central circardian regulator. Nature 470:110-114.

Ware JH (2000) Particulate air pollution and mortality: clearing the air. N. Engl. J. Med. 343:1798-1799.

Warheit DB, Hartsky MA (1993) Role of alveolar macrophages chemotaxis and phagocytosis in pulmonary clearance responses to inhaled particles: comparisons among rodent species. Microsc. Res. Tech. 26:412-422.

Warheit DB, Hartsky MA, Stefaniak MS (1988) Comparative physiology of rodent pulmonary macrophages: in vitro functional responses. J. Appl. Physiol 64:1953-1959.

Warheit DB, Hill LH, Brody AR (1984) Surface morphology and correlated phagocytic capacity of pulmonary macrophages lavaged from the lungs of rats. Exp. Lung Res. 6:71-82.

Warheit DB, Hill LH, George G, Brody AR (1986) Time course of chemotactic factor generation and the corresponding macrophage response to asbestors inhalation. Am. Rev. Respir. Dis. 134:128- 138. 
Warheit DB, Reed KL, Sayes CM (2009). A role for nanoparticle surface reactivity in facilitating pulmonary toxicology and development of a base set of hazard assays as a component of nanoparticle risk management. Inhal. Toxicol. 21:61-67.

Warner AE (1996) Pulmonary intravascular macrophages: role in acute lung injury. Clin. Chest Med. 17:125-135.

Warner AE, Barry BA, Brain JD (1986) Pulmonary intravascular macrophages in sheep: morphology and function of a novel constituent of the mononuclear phagocyte system. Lab. Invest. 55:276-288.

Warner AE, Brain JD (1984) Intravascular pulmonary macrophages in ruminants actively participate in reticuloendothelial clearance of particles. Fed. Proc. 43:1001.

Warner AE, Brain JD (1986) Intravascular macrophages: a novel cell removes particles from blood. Am. J. Physiol. 19:R728-732.

Warner AE, Brain JD (1990) The cell biology and pathogenic role of pulmonary intravascular macrophages. Amer. J. Physiol. 258:L1-L12.

Warner AE, Barry BE, Brain JD (1986) Pulmonary intravascular macrophages in sheep: morphology and function of a novel constituent of the mononuclear phagocyte system. Lab. Invest. 55:276-288.

Warner AE, Molina RM, Brain JD (1987) Uptake of bloodborne bacteria by pulmonary intravascular macrophages and consequent inflammatory responses in sheep. Am. Rev. Respir. Dis. 136:683-690.

Webb TJ, Sumpter TL, Thiele AT, Swanson KA, Wilkes DS (2005) The phenotype and function of lung dendritic cells. Crit. Rev Immun. 25:465-492.

Weibel ER (1984) The pathways for oxygen: structure and function in the mammalian respiratory system. Harvard University Press. Harvard (MA).

Weibel ER (1985) Lung cell biology. In: Handbook of physiology: respiration, vol. 3, sect 2. (Fishman AP, ed). American Physiological Society, Bethesda, pp. 47-91.

Weissler JC, Lyons CR, Lipscomb MF, Toews GB (1986) Human pulmonary macrophages: functional comparison of cells obtained from whole lung by bronchoalveolar lavage. Am. Rev. Respir. Dis. 133:473-477.

Welsch U (1981) Fine structural and enzyme histochemical observations on the respiratory epithelium of the caecilian lungs and gills, a contribution to the understanding of the evolution of the vertebrate respiratory epithelium. Arch. Histol jap. 44:117-133.

Welsch U (1983) Phagocytosis in the amphibian lung. Anat. Anz. 154:323-327.

Welsch U, Müller W (1980) Feinstrukturelle Beobachtungen am Alveolarepithel von Reptilien ubterschiedlicher Lebensweise. Z. microsk.-anat. Forsch. 94:333-348.

Wheeldon EB, Hansen-Flaschen JH (1986) Intravascular macrophages in the sheep lung. J. Leukocyte Biol. 40:657-661.

Whitsett JA (2002) Intrinsic and innate defenses in the lung: intersection of pathways regulating lung morphogenesis, host defense, and repair. J. Clin. Invest. 109:565-522.

Wichman HE, Peters A (2000) Epidemiological evidence of the effects of ultrafine particle exposure. Philos. Trans. R. Soc., Lond. A 358:2751-2769.

Wideman RE (2005) Pathophysiology of heart/lung disorders: pulmonary hypertension syndrome in broiler chickens. World's Poult. Sci. J. 57:289-307.

Winkler GC (1988) Pulmonary intravascular macrophages in domestic animal species: review of structural and functional properties. Am. J. Anat. 181:217-234. 
Winkler GC (1989) Review of the significance of pulmonary intravascular macrophages with respect to animal species and age. Exp. Cell Biol. 57:281-286.

Winkler GC, Cheville N (1985) Monocytic origin and postnatal mitosis of intravascular macrophages in the porcine lung. J. Leukocyte Biol. 38:471-480.

Winkler GC, Cheville N (1987) Postnatal colonization of porcine lung capillaries by intravascular macrophages: an ultrastructural, morphometric analysis. Microvasc. Res. 33:223-232.

Wismar BL, Dehring DJ, Lowery BD, Cloutier CT, Carey LC (1984) Electron microscopic evidence of intravascular phagocytosis in the lungs of a porcine model of septic acute respiratory failure. Am. Rev. Respir. Dis. 129:A290.

Wizeman TM, Laskin DL (1994) Enhanced phagocytosis, chemotaxis, and production of reactive oxygen intermediates by interstitial lung macrophages following acute endotoxemia. Am. J. Respir. Cell Miol. Biol. 11:358-365.

Wu L, Liu YJ (2007) Development of dendritic-cell lineages. Immunity 26:741-750.

Xia WJ, Pinto CE, Kradin RL (1995) The antigen-presenting activities of $\mathrm{Ia}^{+}$dendritic cells shift dynamically from lung to lymph node after an airway challenge with soluble antigen. J. Exp. Med. 181:1275-1283.

Yamaya M, Fukushima T, Sekisawa K, Ohrui T, Sasaki H (1995) Cytoplasmic motility reflects phagocytic activity in alveolar macrophages from dog lungs. Respir. Physiol. 101:199-205.

Yamaya M, Sayasu K, Sekisawa K, Yamauchi K, Shimura S et al. (1989) Acute effect of cigarrette smoke on cytoplasmic motility of alveolar macrophages in dogs. J. Appl. Physiol. 66:1172- 1178.

Yamaya M, Sayasu K, Sekisawa K, Yamauchi K, Shimura H et al. (1990) Mechanisms of decrease in cytoplasmic motility of alveolar macrophages during immediate asthmatic response in dogs. Am. J. Physiol. 258:L220-L226.

Yanagawa H, Yano S, Haku T, Ohmoto Y, Sone S (1996) Interleukin-1 receptor antagonist in pleural effusion due to inflammatory and malignant lung disease. Eur. Respir. J. 9:1211-1216.

Yewdell JW, Dolan BP (2011) Cross-dressers turn on T-cells. Nature 471:581-582.

Yoshikawa T, Hill TE, Yoshikawa N, Popov VL, Galindo CL et al. (2010) Dynamic innate immune responses of human bronchial epithelial cells to severe acute respiratory syndrome-associated coronavirus infection. PLoS ONE 5(1):e8729 (doi:10.1371/journal.pone.0008729).

Yu CP, Chen YK, Morrow PE (1989) An analysis of alveolar macrophage mobility kinetics at dust overloading of the lungs. Fundam. Appl. Toxicol. 13:452-459.

Zeltner T, Caduff J, Gehr P, Pfenninger J, Burri P (1987) The postnatal development and growth of the human lung. I. Morphometry. Respir. Physiol. 67:247-267.

Zetterberg G, Johansson A, Lundahl J, Lundoborg M, Sköld CM et al. (1998) Differences between rat alveolar and interstitial macrophages 5 weeks after quartz exposure. Am. J. Physiol. 274:L226- L234.

Zhou LJ, Tedder TF (1995) A distinct pattern of cytokine gene expression by human CD83+ blood dendritic cells. Blood 86:3295-3301.

Zigmond SH, Hirsch JG (1979) Effects of cytochalasin B on polymorphonuclear leukocyte locomotion, phagocytosis and glycolysis. Exp. Cell Res. 73:383-393. 
Zlotnik A, Crowle AJ (1992) Lymphokine-induced mycobacteriostatic activity in mouse pleural macrophages. Infect. Immun. 37:786-793.

Zlotnik A, Vatter A, Hayes RL, Blumentahl E, Crowle AJ (1982) Mouse pleural macrophages: characterization and comparison with mouse alveolar and peritoneal macrophages. J Reticuloendothel. Soc. 31:207-220.

Zwilling BS, Campolito LB, Reiches NA (1982) Alveolar macrophage subpopulations identified by differential centrifugation on discontinuous albumin density gradient. Am. Rev. Respir. Dis. 125:448-452. 


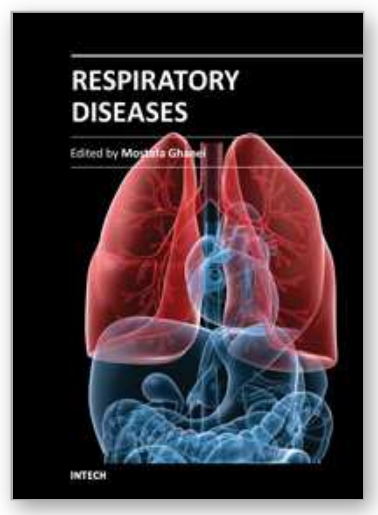

\author{
Respiratory Diseases \\ Edited by Dr. Mostafa Ghanei
}

ISBN 978-953-307-964-6

Hard cover, 242 pages

Publisher InTech

Published online 01, February, 2012

Published in print edition February, 2012

Medicine is an ever-changing science. In this regard, Respiratory medicine is not an exception and has been evolving during recent years. As new research broadens our knowledge, advanced methods for diagnoses are better understood, providing genetic and underlying pathophysiology of diseases and new clinical experiences. Consequently, publications of new resources along with revisions of previous ones are required. The book Respiratory Diseases brings practical aspects of pulmonary diseases. It contains the result of years of experience through expert clinicians in this field from different scientific centers. The respiratory diseases are discussed according to epidemiology, pathology, diagnosis, treatment, and prognosis. It includes updated resources of the pathogenesis and some molecular aspects of the aforementioned diseases and is recommended reading for all clinicians and medical students, especially pulmonologists, to access highlighted respiratory diseases in this book.

\title{
How to reference
}

In order to correctly reference this scholarly work, feel free to copy and paste the following:

J.N. Maina (2012). Cellular Defences of the Lung: Comparative Perspectives, Respiratory Diseases, Dr. Mostafa Ghanei (Ed.), ISBN: 978-953-307-964-6, InTech, Available from:

http://www.intechopen.com/books/respiratory-diseases/cellular-defences-of-the-lung-comparative-perspectives

\section{INTECH}

open science | open minds

\author{
InTech Europe \\ University Campus STeP Ri \\ Slavka Krautzeka 83/A \\ 51000 Rijeka, Croatia \\ Phone: +385 (51) 770447 \\ Fax: +385 (51) 686166 \\ www.intechopen.com
}

\author{
InTech China \\ Unit 405, Office Block, Hotel Equatorial Shanghai \\ No.65, Yan An Road (West), Shanghai, 200040, China \\ 中国上海市延安西路65号上海国际贵都大饭店办公楼 405 单元 \\ Phone: +86-21-62489820 \\ Fax: +86-21-62489821
}


(C) 2012 The Author(s). Licensee IntechOpen. This is an open access article distributed under the terms of the Creative Commons Attribution 3.0 License, which permits unrestricted use, distribution, and reproduction in any medium, provided the original work is properly cited. 